Article

\title{
Appropriate Use of Lime in the Study of the Physicochemical Behaviour of Stabilised Lateritic Soil under Continuous Water Ingress
}

\author{
Chukwueloka Okeke ${ }^{1} \oplus$, Samuel Abbey ${ }^{2, *}{ }^{\circledR}$, Jonathan Oti ${ }^{3} \oplus$, Eyo Eyo ${ }^{2}$, Abiola Johnson ${ }^{1}$, Samson Ngambi ${ }^{4}(\mathbb{D}$, \\ Tamunoene Abam ${ }^{5}$ and Mgboawaji Ujile ${ }^{2}$ \\ 1 Department of Civil Engineering, College of Engineering, Covenant University, Ota P.M.B. 1023, Nigeria; \\ chukwueloka.okeke@covenantuniversity.edu.ng (C.O.); biola.johnson@yahoo.com (A.J.) \\ 2 Faculty of Environment and Technology, Department of Geography and Environmental Management, \\ Civil Engineering Cluster, University of the West of England, Bristol BS16 1QY, UK; eyo.eyo@uwe.ac.uk (E.E.); \\ mgboawaji.ujile@uwe.ac.uk (M.U.) \\ 3 School of Engineering, Faculty of Computing, Engineering and Science, University of South Wales, \\ Pontypridd CF37 1DL, UK; Jonathan.oti@southwales.ac.uk \\ 4 School of Energy, Construction and Environment, Faculty of Engineering, Environment and Computing, \\ Coventry University, Coventry CV1 5FB, UK; apx290@coventry.ac.uk \\ 5 Institute of Geosciences and Space Technology, Rivers State University, Nkpolu-Oroworukwo, \\ Port Harcourt P.M.B. 5080, Nigeria; Abam.kingdom@ust.edu.ng \\ * Correspondence: samuel.abbey@uwe.ac.uk
}

check for updates

Citation: Okeke, C.; Abbey, S.; Oti, J.; Eyo, E.; Johnson, A.; Ngambi, S.; Abam, T.; Ujile, M. Appropriate Use of Lime in the Study of the Physicochemical Behaviour of Stabilised Lateritic Soil under Continuous Water Ingress. Sustainability 2021, 13, 257. https: / doi.org/10.3390/su13010257

Received: 9 December 2020 Accepted: 25 December 2020 Published: 29 December 2020

Publisher's Note: MDPI stays neutral with regard to jurisdictional clai$\mathrm{ms}$ in published maps and institutional affiliations.

Copyright: (C) 2020 by the authors. Licensee MDPI, Basel, Switzerland. This article is an open access article distributed under the terms and conditions of the Creative Commons Attribution (CC BY) license (https:// creativecommons.org/licenses/by/ $4.0 /)$.
Abstract: Lime stabilisation is one of the traditional methods of improving the engineering properties of lateritic soils for use as subgrade and foundation materials for the construction of road pavements and highway embankments. Understanding the mechanical performance of lime-stabilised lateritic subgrades in terms of their durability under continuous water ingress will improve environmental sustainability by conserving scarce natural resources and reducing the environmental impacts of repair and replacement of pavements. However, there are several conflicting reports on the durability of lime-stabilised soils subjected to continuous water ingress and harsh environmental conditions. Therefore, this paper evaluates the influence of leaching on the physicochemical behaviour and durability of lime-stabilised lateritic soil under continuous water ingress, simulating the typical experience in a tropical environment. Variations in the strength and durability of the lateritic soil at various lime contents $(0,2.5,5,7.5,10,15$, and $20 \mathrm{wt}$.\%) and soaking periods $(3,7,14$ and 28 days) were evaluated by performing the California bearing ratio tests before and after subjecting the limelateritic soil (LLS) samples to continuous leaching using two modified leaching cells. Furthermore, physicochemical analysis was performed to assess the variation of cation concentrations and changes in the physical properties of the pore fluid as the leaching time progressed from 3 to 28 days. The results show that the minimum strength reduction index of the soil corresponds to its lime stabilisation optimum (LSO). Electrical conductivity decreased monotonically and almost uniformly with an increase in leaching time, irrespective of lime content. So, too, was calcium concentration and to a lesser degree for $\mathrm{pH}$ and potassium concentration. Adverse changes in the physicochemical behaviour of the LLS samples occurred at lime contents below and slightly above the optimum lime content of the soil. Whereas permanent pozzolanic reactions occurred at lime contents above the LSO and thus resulted in a 45-fold increase in strength and durability. The results are significant for reducing the detrimental effect of the leaching-induced deterioration of flexible pavements founded on tropical floodplains.

Keywords: lateritic soil; lime stabilization; subgrade; leaching; CBR value; durability 


\section{Introduction}

The availability of sustainable civil infrastructure systems, such as transportation, water and wastewater, electric power, and communications, is essential for the growth and development of urban areas. The rapid growth in the population of urban areas, as witnessed in Africa and Asia, has placed a need for the development of sustainable civil infrastructure, including highways, runways, and earth dams on floodplains and reclaimed lands. However, numerous regional and municipal infrastructure projects founded on floodplains and reclaimed lands have failed as a result of the poor engineering properties of the materials within these environments, in addition to the effects of intense precipitation and other harsh environmental conditions [1]. These engineering failures have been attributed to the high cost of excavating and replacing problematic soils with suitable materials and the strict legislative rules that govern the utilisation of these scarce natural resources for earthworks construction purposes. The adverse effect of rainfall-induced water ingress into pavement structural layers and its impact on the service life of flexible pavements and railway subgrades have been reported in recent literature [2-11].

Lateritic soils and other tropical residual soils constitute the dominant lithologic units in many parts of southern Nigeria. These soils are end-products of the chemical weathering of rock. Hence, their formation and physicochemical properties depend on rainfall, temperature, topography, humidity, vegetation, time, and chemical composition of the parent rock $[12,13]$. The main distinctive feature of lateritic soils is the high amount of sesquioxides of iron and aluminium, with kaolinite being the dominant clay mineral [14,15]. Lateritic soils are extensively used as subbase and subgrade for the construction of runways, road embankments and highways, and other civil infrastructure such as earth dams. However, these soils are relatively unstable. They generally possess varying physical and engineering properties which are influenced by several factors, including the nature of the parent rock, age, topography, climate, and vegetation [16-18]. Furthermore, the engineering properties of laterite and other tropical residual soils are subject to routine modifications as a result of the permanent alteration of their mineralogical characteristics under varying moisture conditions [19]. Hence, their susceptibility to changes under high temperature and moisture conditions, especially in wet tropical regions, limits their utilisation as suitable materials for earthworks construction [1,17,20-22]. Therefore, the stabilisation of lateritic soils with suitable additives is crucial to increasing the long-term stability of highway pavements, earth dams, and road embankments.

Extensive laboratory investigations have been carried out to evaluate the effect of traditional stabilisers, such as lime and cement, on the mechanical performance of lateritic soils and other residual soils [23-32]. The addition of quicklime $(\mathrm{CaO})$ to lateritic soils or clayey soil in the presence of water, leads to a hydration (exothermic) reaction that produces hydrated lime $\mathrm{Ca}(\mathrm{OH})_{2}$. The hydrated lime immediately dissociates in the pore fluid to release calcium $\left(\mathrm{Ca}^{2+}\right)$ and hydroxyl ions $\left(\mathrm{OH}^{-}\right)$and thus results in an increase in electrical conductivity and $\mathrm{pH}$ of the pore fluid [33-35]. The highly alkaline environment produced by the dissolution of $\mathrm{Ca}(\mathrm{OH})_{2}$ promotes the exchange of $\mathrm{Ca}^{2+}$ cations from the lime with the cations (e.g., $\mathrm{Na}^{+}, \mathrm{K}^{+}$, and $\mathrm{Al}^{3+}$ ) on the surface of the negatively charged clay minerals. The increased concentration of $\mathrm{Ca}^{2+}$ ions in the pore fluid modifies the thickness of the diffuse double layer (DDL), promotes the flocculation of the soil particles, and causes a reduction in the plasticity index of the soil, thereby improving the workability of the soil. These series of reactions, which occur at the optimum lime content (OLC) of the soil, give rise to what is generally referred to as lime modified soils [33,36-38]. On the other hand, long-term stabilisation occurs when lime is added above the soil's OLC. The highly alkaline environment of the pore fluid influences the dissolution of siliceous and aluminous compounds within the lattices of the clay minerals, which then reacts with $\mathrm{Ca}^{2+}$ ions in the pore fluid to produce some cementitious products such as calcium-silicate-hydrate (C-S-H), calcium-aluminate-hydrate (C-A-H) and calcium-aluminate-silicate-hydrate (CA-S-H). The long-term duration of these pozzolanic reactions within a highly alkaline 
environment promotes the formation of C-S-H and C-A-H, which bind the soil particles together, causing a long-term increase in the strength and stiffness of the treated soil [39-48].

Although significant improvements in strength and stiffness of tropical residual soils treated with lime and other calcium-based additives have been reported, their durability and long-term stability under harsh environmental conditions have not been fully understood. Some researchers reported that the durability of chemically-stabilised soils tends to decrease with time under certain climatic conditions such as freeze-thaw cycles [9,49], wetting-drying cycles [50,51], and leaching via continuous water circulation $[52,53]$. Leaching-induced deterioration of chemically stabilised subbases and subgrades occurs as a result of rainfall-induced water ingress into pavement structural layers, which adversely modify the physicochemical characteristics of the stabilised material by the gradual removal of the chemical constituents of the stabiliser. Consequently, numerous cases of distresses in pavement structures have been recorded even after standard soil stabilisation design procedures have been followed [54-58]. Therefore, an in-depth understanding of the physicochemical behaviour of lime-stabilised lateritic soil under continuous water ingress is essential to improving the strength and stiffness of materials used as subbases and subgrades for road construction.

There is sparse research to date on the durability and long-term stability of chemically stabilised soils under continuous water ingress, especially in seasonally flooded tropical environments. For instance, Chittoori et al. [53] investigated the long-term stability of limeand cement-treated expansive clays subjected to accelerated leaching tests by monitoring the variation of $\mathrm{pH}$ and calcium concentrations in the leachate. The authors found that the soils treated with $6 \mathrm{wt} . \%$ lime showed a slight decrease in strength, while the soils treated with lower lime contents ( 3 and $4 \mathrm{wt} . \%$ ) exhibited a considerable decrease in strength after subjecting them to 14 cycles of leaching. Obuzor et al. [55] evaluated the durability of pavement interlayers and embankments founded on floodplains by stabilising Lower Oxford Clay with lime-activated ground granulated blast furnace slag (GGBS). The authors found that the durability index of the lime-clay blends was significantly influenced by the percentage of GGBS in the system, which amplified the formation of more C-S-H gels that increased the strength and durability of the stabilised soil. McCallister and Petry [59,60] evaluated the durability of lime-treated plastic clays subjected to continuous accelerated leaching tests. The authors found that the soil-lime mixtures prepared with lime significantly above their lime modification optimum (LMO) had the highest concentration of $\mathrm{Ca}^{2+}$ ions in their leachate, which decreased with a corresponding decrease in lime content. The authors concluded that the durability of lime-treated soils depends on their LMO. Khattab et al. [61] employed a combination of wetting-drying tests and leaching tests in an attempt to study the durability of lime-treated clayey soil. The authors observed that leaching had no detrimental effect on the mechanical properties of the soil due to the insignificant quantity of lime recovered from the leachate. On the other hand, Le Runigo et al. [62] investigated the long-term behaviour of lime-treated silt subjected to long-term hydraulic conditions. The authors found that subjecting the soil-lime mixtures to water circulation caused a considerable decrease in shear strength and durability. Deneele et al. [63] carried out medium- to long-term (110 to 320 days) accelerated leaching tests to evaluate the durability of lime-stabilised silt under continuous water circulation. Their results revealed that the strength and durability of the soil-lime mixtures could be related to the soil's LMO. They concluded that long-term water circulation has the potential to reduce the durability of water retaining structures unless lime is added in excess of the soil's LMO. In addition to many conflicting reports regarding the leaching-induced deterioration of pavement structural layers, little or no research has been done on the durability and physicochemical behaviour of lime-stabilised tropical residual soils under continuous water circulation, given their unique mineralogical and physicochemical properties. Moreover, the majority of the leaching tests were carried out using experimental devices that were designed to induce accelerated water circulation through the soil $[53,63,64]$, which tends to cause excessive leaching that could lead to a decrease in the strength and durability of the soil. 
This paper presents a comprehensive experimental investigation designed to evaluate the physicochemical behaviour of lime-stabilised lateritic soil subjected to continuous water ingress. The main focus of this research was to investigate the influence of rainfall-induced water ingress on the durability of lateritic soil treated with various quantities of lime. In view of this objective, the LLS samples were prepared by adding lime in quantities that were below and above the OLC of the lateritic soil. Fundamental geotechnical tests such as particle size analysis, standard Proctor compaction tests, Atterberg limits tests, and CBR tests were performed on the natural soil and the LLS samples to determine their engineering properties. Column leaching tests were performed on the natural soil and the LLS samples to evaluate the effect of water ingress on their durability and engineering properties. Furthermore, scanning electron microscopy (SEM) and X-ray diffraction (XRD) analyses were carried out to study the microstructural and mineralogical behaviour of the soil samples at different lime contents and leaching periods.

\section{Significance and Novelty of This Research}

Lateritic soils are the most abundant earth material in the tropical and subtropical regions of the world. These soils are mostly used in the construction industry for the production of compressed earth blocks (CEBs). They are used as fill materials for the construction of earth dams and road embankments, and as subbases and subgrades for the construction of flexible pavements. Most lateritic soils are sensitive to drying, which can lead to irreversible changes in their engineering properties due to the presence of certain minerals, such as allophane, hydrated halloysite, gibbsite and goethite. These poor engineering properties of lateritic soils affect the service life of civil engineering structures built on them and can lead to periodic repair and maintenance. Therefore, the utilisation of traditional stabilisers, such as cement and lime, is essential to improving the engineering properties of lateritic soils, thereby improving the resilience and sustainability of civil infrastructure, especially in developing countries.

However, lateritic soils are predominantly composed of silica and sesquioxides of iron and aluminium. Hence, the addition of an excess amount of lime to the soils can detrimentally affect their engineering properties by increasing their liquid limit and plasticity index. Furthermore, numerous studies have found that expansive soils stabilised below their OLC are susceptible to leaching-induced deterioration via continuous water ingress. One important criterion that must be met to ensure the sustainability and long-term performance of roads and highway embankments founded on lime-stabilised lateritic soil in seasonally flooded tropical environments is that the soil must be stabilised above its OLC or at its LSO. Therefore, the significance of this research lies in the appropriate use of lime as opposed to cement, and the considerable reduction of carbon footprint via the addition of an optimum amount of lime required to improve the durability of stabilised lateritic soils and reduce leaching-induced pavement deterioration. Improving the durability of stabilised soils will ultimately reduce the socioeconomic impacts of road construction and maintenance in seasonally flooded tropical environments. This would enhance the utilisation of lime-stabilised residual soils as subgrades and subbases for sustainable construction of roads and highway embankments. The consumption of cement, on a per capita basis, is second only to water, and there is no readily available substitute. Lime requires less energy to produce compared to cement because the basic raw material (limestone) can be burned at lower temperatures of $900{ }^{\circ} \mathrm{C}$ in comparison to the higher temperature of $1300{ }^{\circ} \mathrm{C}$ required for the calcination of argillaceous limestone during the production of Portland cement (PC). Also, some of the carbon dioxide $\left(\mathrm{CO}_{2}\right)$ produced during firing is reabsorbed by lime as it hardens, and lime can be produced locally on a small scale, thereby reducing pollution by limiting transport distances. Therefore, the appropriate use of lime in the study of the behaviour of stabilised lateritic soil under continuous water ingress can undoubtedly, be beneficial in creating and maintaining infrastructural systems that are more green-friendly. 
Previous studies on the leaching-induced deterioration of pavement interlayers were carried out using customised leaching cells that allow for the imposition of confining pressures on the soil specimens. These imposed confining pressures, which range from 20 to $120 \mathrm{kPa}$, can induce excess pressure on the flow, which could potentially lead to accelerated leaching of the chemical constituents of the stabilised soil. Therefore, the novelty of this research lies in the replication of natural field conditions of leaching-induced pavement deterioration by subjecting the soil samples to continuous water ingress with no confining pressures imposed on the flow.

\section{Materials and Methods}

\subsection{Materials}

This research made use of lateritic soil obtained from a borrow pit along Idiroko road, Ota $\left(6^{\circ} 40^{\prime} 51^{\prime \prime} \mathrm{N}, 3^{\circ} 9^{\prime} 10^{\prime \prime} \mathrm{E}\right)$, in Ogun State, southwest Nigeria. The soil was initially air-dried at room temperature $\left(25 \pm 1^{\circ} \mathrm{C}\right)$ for a minimum of 7 days. Then, the air-dried soil was manually pulverised and passed through No. 4 sieve $(4.76 \mathrm{~mm})$ to remove pebbles and organic debris. The results obtained from particle size distribution analysis performed following ASTM D6913/D6913M-17 [65] and ASTM D7928-17 [66] standards show that the soil is dominantly comprised of sand $(46 \%)$, silt $(22 \%)$ and clay $(32 \%)$. The soil's average natural moisture content and specific gravity were $9 \%$ and 2.69 , respectively, while other physical properties of the lateritic soil are summarised in Table 1. Lateritic soils are primarily comprised of primary minerals such as illite, kaolinite, feldspar (microcline), mica (muscovite), and quartz, and secondary minerals such as limonite, hematite, gibbsite, and goethite [16]. The traditional stabiliser used in this research was commercially available quicklime (calcium oxide, $\mathrm{CaO}$ ). About $95 \%$ of the lime, in its pulverised form, passed through the ASTM No. 230 sieve $(63 \mu \mathrm{m})$. The chemical compositions of the materials, as determined by X-ray fluorescence, are summarised in Table 2.

Table 1. Geotechnical properties of lateritic soil.

\begin{tabular}{cc}
\hline Property & Value \\
\hline Percent passing sieve No. 200 & 53 \\
Liquid limit (\%) & 49 \\
Plastic limit (\%) & 21 \\
Plasticity index (\%) & 28 \\
AASHTO & A-7-6 \\
OMC (\%) & 16 \\
MDD $\left(\mathrm{kN} / \mathrm{m}^{3}\right)$ & 17.95 \\
CBR (unsoaked) (\%) & 5 \\
\hline
\end{tabular}

Table 2. Chemical compositions of lime and lateritic soil.

\begin{tabular}{|c|c|c|c|c|c|c|c|c|c|c|c|c|c|}
\hline \multirow{2}{*}{ Material } & \multicolumn{13}{|c|}{ Oxide Composition (wt.\%) } \\
\hline & $\mathrm{SiO}_{2}$ & $\mathrm{Al}_{2} \mathrm{O}_{3}$ & $\mathrm{Fe}_{2} \mathrm{O}_{3}$ & $\mathrm{TiO}_{2}$ & $\mathrm{~K}_{2} \mathrm{O}$ & $\mathrm{ZrO}_{2}$ & $\mathrm{MgO}$ & $\mathrm{CaO}$ & $\mathrm{MnO}$ & $\mathrm{Mn}_{2} \mathrm{O}_{3}$ & $\mathrm{CuO}$ & $\mathrm{Na}_{2} \mathrm{O}$ & LOI \\
\hline Lateritic soil & 53.56 & 11.62 & 23.45 & 1.31 & 0.98 & 0.04 & 0.53 & 0.03 & 0.09 & - & 0.02 & 0.18 & 7.44 \\
\hline Lime & 1.0 & 0.3 & 0.5 & - & - & - & 2.0 & 94.0 & & 1.2 & - & - & - \\
\hline
\end{tabular}

\subsection{Methods}

\subsubsection{Determination of Optimum Lime Content (OLC)}

Before the soil was mixed with lime, the OLC test was carried out to determine the minimum lime percentage for the lateritic soil following ASTM D6276-19 [67]. The OLC has been defined as the smallest quantity of lime required for reducing the plasticity and swell potential of a reactive soil, and for the initiation of mid- to long-term pozzolanic reactions [36]. Eades and Grim [38] reported that a highly alkaline environment, which gen- 
erally corresponds to a $\mathrm{pH}$ value of 12.4 , is required to initiate pozzolanic reactions that enhance the crystallisation of cementitious products (C-S-H and C-A-H), due to the reactions between the dissolved $\mathrm{Ca}^{2+}$ ions of lime and $\mathrm{Si}^{4+}$ and $\mathrm{Al}^{3+}$ ions of the clay minerals. Bell [68] noted that the lime fixation point of most soils, which is traditionally lower than the OLC, ranges between $1 \%$ and $3 \%$ lime by dry weight of soil. The addition of lime to a reactive soil results in cation exchange process that leads to a high concentration of $\mathrm{Ca}^{2+}$ ions in the pore fluid, which causes a reduction in the DDL thickness, followed by flocculation-agglomeration of the clay particles.

The OLC test was conducted by mixing $50 \mathrm{~g}$ of an oven-dried soil containing various percentages of lime $(1 \sim 10 \%)$ with about $200 \mathrm{~mL}$ of distilled water to obtain an aqueous solution. The solution was stirred at regular intervals while the $\mathrm{pH}$ values were taken after $3 \mathrm{~h}$. The plot of $\mathrm{pH}$ versus lime content determined at standard room temperature $\left(25 \pm 1{ }^{\circ} \mathrm{C}\right)$ is shown in Figure 1. It is evident from the plot that the OLC of the soil is $4 \%$. Beyond this value, further increase in lime content did not cause any apparent increase in $\mathrm{pH}$. Therefore, in view of the primary objective of this research, which was to evaluate the long-term stability of lime-stabilised lateritic soil under continuous water ingress, various quantities of lime were added to the lateritic soil in percentages that were below and above the soil's OLC. Hence, the LLS samples were prepared by adding various quantities of lime in the range of $0,2.5,5,7.5,10,15$, and $20 \%$ by dry weight of soil. Each of the soil samples was manually mixed with distilled water to the desired compaction water content and left in an air-tight container for a minimum of $3 \mathrm{~h}$ to ensure uniform moisture distribution.

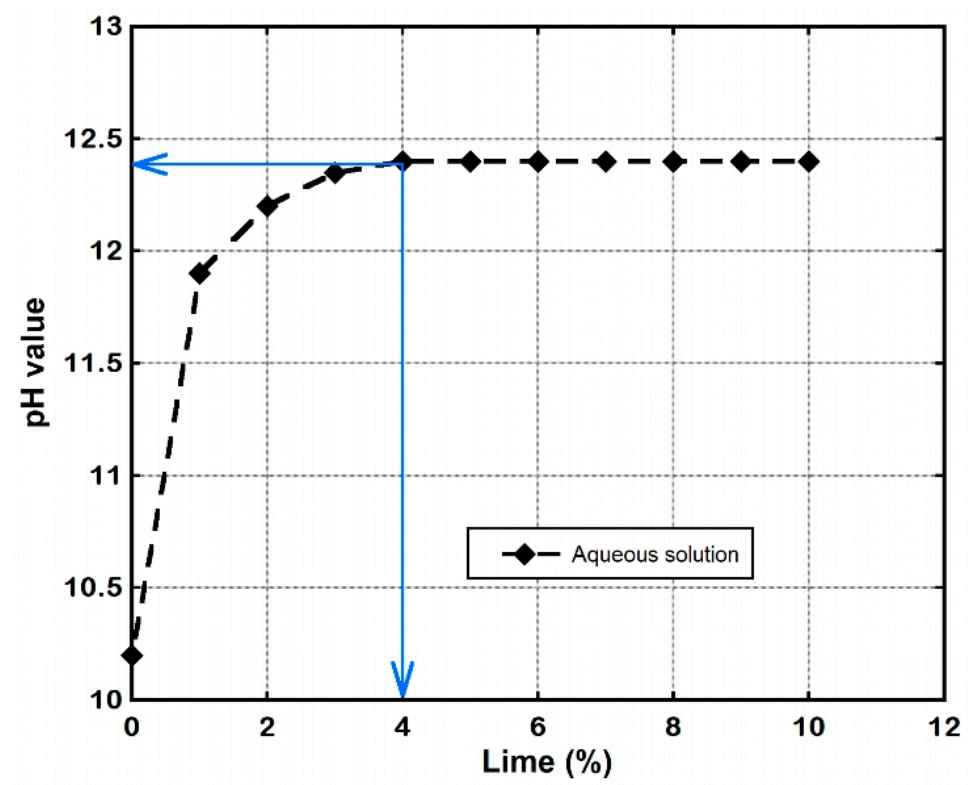

Figure 1. Trends of $\mathrm{pH}$ values determined from optimum lime content test.

\subsubsection{Geotechnical Tests}

Atterberg limits tests were performed to determine the liquid limit (LL), plastic limit (PL), and plasticity index (PI) of the natural soil and the LLS samples following ASTM D4318-17e1 [69] standards. The standard Proctor compaction tests were conducted to determine the optimum moisture content $\left(w_{\text {opt }}\right)$ and the maximum dry unit weight $\left(\gamma_{\mathrm{dmax}}\right)$ of the natural soil and the LLS samples in accordance with ASTM D698-12e2 [70] standards. In the first place, the air-dried natural soil, which has been divided into five (5) different samples and mixed with different volumes of distilled water, was placed in a standard mould (dia., $101.6 \mathrm{~mm}$ ) in lifts of 3 layers, with each layer receiving 25 number of blows of the standard hammer. Subsequently, corresponding values of $\gamma_{\mathrm{dmax}}$ and $w_{\text {opt }}$ were determined from the compaction curve followed by those of the LLS samples.

The CBR test was carried out to evaluate the durability and engineering behaviour of the LLS samples when subjected to continuous water ingress. The CBR test is one of the 
methods used to evaluate the mechanical properties of earth materials in order to determine their suitability for use as subgrades, subbases and base courses for highway construction. The soil samples were compacted in a standard mould at their $\gamma_{\mathrm{dmax}}$ and $w_{\text {opt }}$ as determined from standard Proctor compaction test. A $4.5 \mathrm{~kg}$ surcharge mass was placed on each mould before soaking in water for periods ranging from 3 to 28 days (Figure 2a). At the end of each soaking period, a $4.9 \mathrm{~cm}$ diameter piston was allowed to penetrate the soil samples at a constant penetration rate of $1.27 \mathrm{~mm} / \mathrm{min}$ (Figure $2 \mathrm{~b}-\mathrm{d}$ ). From the load-penetration curves, the loads corresponding to 2.5 and $5 \mathrm{~mm}$ depths of penetration were divided by the standard loads at the same depth of penetration to give the CBR value. The tests were carried out in two phases: Phase I (pre-leaching phase) and Phase II (post-leaching phase). In phase I, the CBR test was performed on the soil mixtures after they were soaked in water for $3,7,14$, and 28 days and before subjecting them to column leaching tests. While in phase II, the CBR test was performed at the end of each leaching period, which varied from 3 to 28 days. Both phases of the CBR tests were performed on the lateritic soil and the LLS samples under soaked condition following ASTM D1883-16 [71] standards. All the tests were performed at standard room temperature.
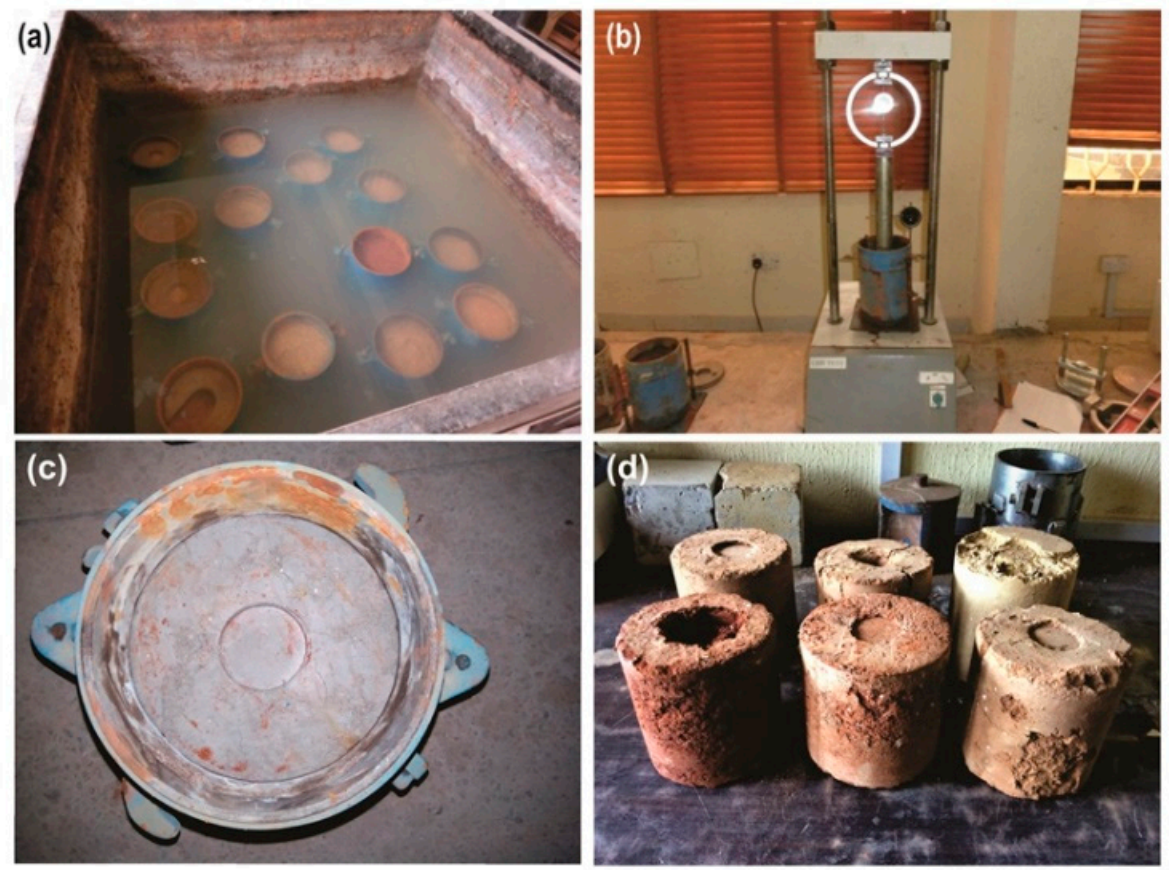

Figure 2. (a) Soaking of natural soil and lime-lateritic soil samples (b) Experimental device for determination of CBR values of natural soil and lime-lateritic soil samples (c) Standard mould used for the CBR test and (d) lime-lateritic soil samples extruded from the mould after CBR test.

\subsubsection{Column Leaching Tests and Physicochemical Analyses}

The effect of rainfall-induced water ingress on the physicochemical behaviour of the natural soil (control specimen) and the LLS samples was evaluated by carrying out column leaching experiments using two Perspex acrylic columns with an internal diameter of $7 \mathrm{~cm}$ and height of $25 \mathrm{~cm}$. (Figure 3). The details of the experimental setup and testing conditions adopted for the leaching test coupled with the procedure for the physicochemical analysis have been extensively described by $[57,72]$. Percolation through the soil samples was simulated using a water tank containing distilled water. The water tank was set up such that it imposes a constant hydraulic head of $1 \mathrm{~m}$, which corresponds to a hydraulic gradient of 4 . The hydraulic gradient was applied to simulate flood inundation in seasonally flooded low-land areas [61,73]. Selection of the hydraulic head for the leaching experiments was done based on two conditions [63]. Firstly, the hydraulic head must be at a critical value to ensure adequate interaction between the leaching fluid and the soil. This condition was achieved by applying no confining pressure 
on the leaching fluid, in contrast to the methods adopted by several authors $[52,53,60,61,63]$, who imposed confining pressure values that varied from 20 to $120 \mathrm{kPa}$. Secondly, the hydraulic head must be high enough to allow significant volume of leachate to be collected at appropriate intervals. Preventive measures, such as covering the upper and lower parts of the soil sample with a filter paper and wire mesh, were taken to minimise the erosion of fines into the leachate. The leachate was collected at regular intervals and stored in pre-washed and properly labelled 0.5 L PET bottles.

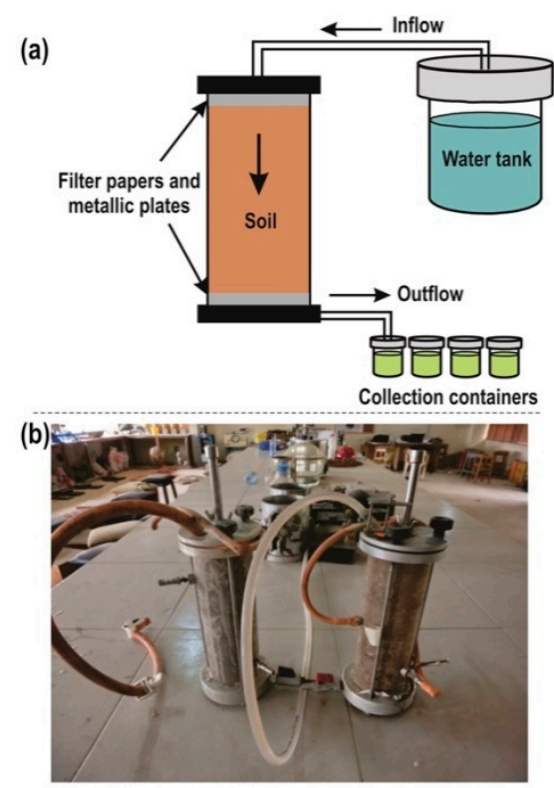

Figure 3. (a) Diagrammatic representation of the experimental setup for column leaching test (b) Typical cylindrical Perspex cells used for the column leaching test (modified from [72]).

Physicochemical analyses were performed on the leachate before, during and after each leaching period. A pre-calibrated multiparameter tester (Oakton PCTestr 35) was used to determine the electrical conductivity (EC) and $\mathrm{pH}$ of the leachate immediately it was collected. The determination of calcium and potassium concentrations in the leachate was carried out using an inductively coupled plasma atomic emission spectrometer (ICPAES). Changes in the mineralogical composition of the soil samples under intense leaching were evaluated by carrying out a series of X-ray diffraction (XRD) analyses. Furthermore, SEM images of the soil samples were used to evaluate their microstructural characteristics.

\section{Results}

\subsection{Effect of Lime on Soil Plasticity}

The effect of lime on the Atterberg limits (liquid limit, plastic limit, and plasticity index) of the soil is shown in Figure 4. The result indicates that the plastic limit (PL) of the soil generally increased with an increase in lime content. In contrast, there was an initial reduction in the liquid limit (LL) and plasticity index (PI) of the soil as lime content increased from $0 \%$ to $5 \%$ (Figure $4 \mathrm{a}$ ). This sudden decrease in LL and PI of the soil is closely connected to the relatively high amount of $\mathrm{Ca}^{2+}$ ions in the pore fluid, which results in a decrease in the DDL thickness, and hence causes a decrease in the liquid limit of the soil [68]. However, further addition of lime beyond 5\% caused an adverse effect on the soil as evidenced by the gradual increase in LL and PI of the soil (Figure 4b). The trends in LL and PI are typical characteristics that distinguish silica-rich lateritic soils from other problem soils [39]. Hence for silica-rich residual soils, further increase in liquid limit is usually triggered by the enhancement of the cation exchange capacity, due to the highly alkaline environment produced by the dissolution of $\mathrm{Ca}(\mathrm{OH})_{2}$, which increases the $\mathrm{pH}$ of the pore fluid [74]. Furthermore, Diamond and Dash, [37,39] observed that the flocculent 
nature of the soil fabric is an essential factor controlling its liquid limit. The more flocculated the soil structure is, the higher the water-holding capacity of the soil, and thus the higher the liquid limit. Similar trend in PI was observed by [27], who investigated the effect of quicklime on the geotechnical properties of lateritic gravel from Burkina Faso. The authors reported that PI decreased from $10.5 \%$ of the natural soil to $8.5 \%$ when treated with 3 wt. $\%$ lime. However, treating the soil with $8 \mathrm{wt} . \%$ lime caused the PI to increase to $11.8 \%$.
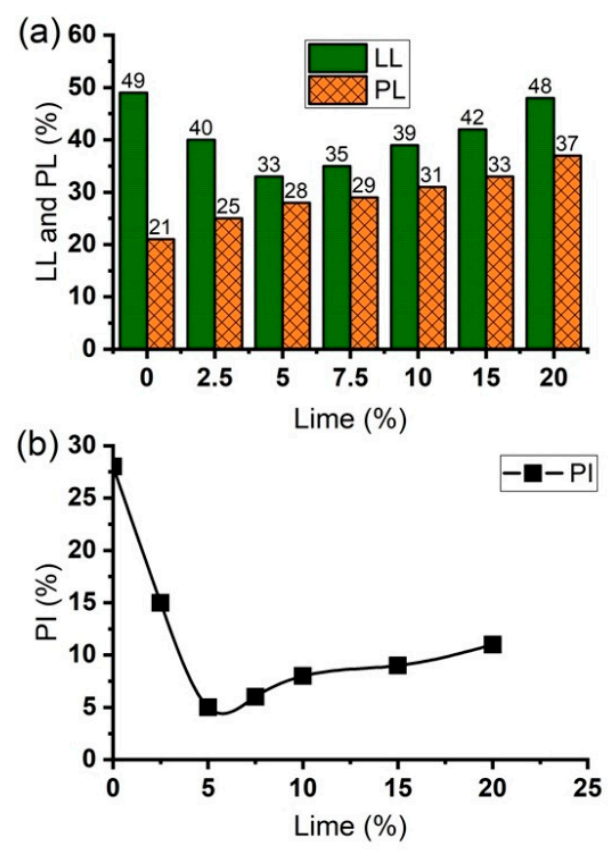

Figure 4. Effect of lime on (a) liquid limit, plastic limit, and (b) plasticity index of natural soil and lime-lateritic soil samples.

\subsection{Compaction}

Figure 5 presents the moisture-density curves of the natural soil and the LLS samples obtained using the standard Proctor compaction test method. From the results, it can be observed that the dry unit weight of the soil decreased with the addition of lime (Figure 5a). In contrast, optimum moisture content $\left(w_{\text {opt }}\right)$ increased with an increase in lime, with minimum and maximum $w_{\text {opt }}$ values of 16 and $23 \%$, for the natural soil and the soil treated with $20 \mathrm{wt} . \%$ lime, respectively. Furthermore, the maximum dry unit weight $\left(\gamma_{\mathrm{dmax}}\right)$ of the soils decreased from $17.95 \mathrm{kN} / \mathrm{m}^{3}$ of the natural soil to $14.1 \mathrm{kN} / \mathrm{m}^{3}$ of the soil treated with $20 \mathrm{wt} . \%$ lime (Figure $5 \mathrm{~b}$ ). Similar trends in $w_{\text {opt }}$ and $\gamma_{\mathrm{dmax}}$ have been observed by other researchers for limestabilised lateritic soil and expansive soils [23-27,75]. Bell [68] observed that treating expansive clays with lime resulted in a decrease in $\gamma_{\mathrm{dmax}}$ with a corresponding increase in $w_{\text {opt }}$ under similar compaction energy. The marked reduction in dry unit weight could be ascribed to the agglomeration of the soil particles with the instantaneous formation of gelatinous compounds, in addition to the low specific gravity of the stabiliser $[28,68,76]$. The increase in $w_{\text {opt }}$ with the addition of lime has been attributed to the high affinity of quicklime for water and the subsequent dissolution of $\mathrm{Ca}(\mathrm{OH})_{2}$ to release $\mathrm{Ca}^{2+}$ ions required for the cation exchange. Furthermore, the increase in $w_{\text {opt }}$ was as a result of an increase in pore size and water-holding capacity within the flocculated soil fabric, coupled with the high demand of water needed for mid- to long-term pozzolanic reactions [74]. 

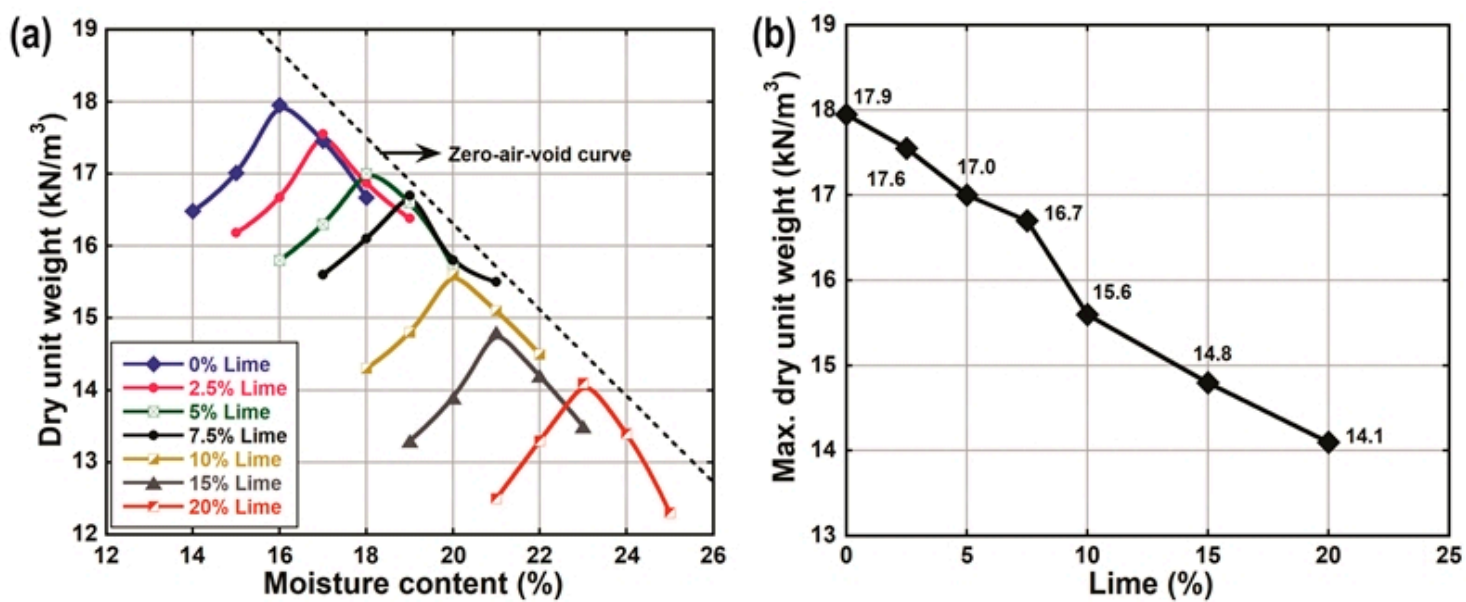

Figure 5. (a) Compaction curves of natural soil and lime-lateritic soil samples (b) Effect of lime on compaction properties of natural soil and lime-lateritic soil samples.

\subsection{California Bearing Ratio and Strength Reduction Index}

The load-penetration curves of the natural soil and the LLS samples before and after they were subjected to leaching via continuous water ingress are shown in Figures 6 and 7, respectively. The results show that the resistance of the LLS samples to the penetration of plunger generally increased as the soaking period increased from 3 to 28 days. The increase in strength (i.e., increase in resistance to penetration of plunger) of the soil-lime mixtures with respect to the soaking period is strongly associated with the highly alkaline nature of the pore fluid, which favours the gradual dissolution of the aluminosilicate constituents of the soil. The dissolved compounds then react with $\mathrm{Ca}^{2+}$ ions to produce hydrated cementitious products responsible for strength gain and long-term stability of the stabilised soils $[40,68,77]$. However, the difference observed from the trends of the load-penetration curves of the LLS samples before and after they were subjected to continuous water ingress suggests a significant reduction in their resilient modulus. The observed reduction in strength is closely linked to the detrimental effect of leaching on the engineering properties of the soil mixtures due to the gradual depletion of $\mathrm{Ca}^{2+}$ ions required for cation exchange and long-term pozzolanic reactions.

Figure 8 shows the variation of CBR values of the LLS samples (at different lime contents and soaking period) before and after they were subjected to continuous water ingress. It is noteworthy to mention that the average pre-leaching and post-leaching CBR values of the natural soil varied between $0.85 \%$ and $0.83 \%$, respectively. The results of the pre-leaching and post-leaching CBR values of the LLS samples indicate that they met the minimum soaked CBR value of $10 \%$ required for use as subgrade for the construction of flexible pavements in Nigeria [78]. This excludes the LLS sample treated with $2.5 \mathrm{wt} . \%$ lime, which had average pre-leaching and post-leaching CBR values of $5.7 \%$ and $4.5 \%$, respectively. The overall trend of the results shows that the CBR values of the stabilised soils increased with a significant increase in lime and soaking period, except for the LLS samples treated with 15 and 20 wt.\% lime, which had lower CBR values under the same soaking and leaching periods. The highest pre-leaching CBR value of $47.1 \%$ was achieved in the LLS sample mixed with $5 \mathrm{wt} . \%$ lime after a soaking period of seven days (Figure 8a). However, the value decreased to $32.2 \%$ and $20.1 \%$ as the soaking period increased from seven to 14 and 28 days, respectively. The rapid increase in strength of the soil mixture is significantly correlated with two major processes: (1) the substitution of $\mathrm{Ca}^{2+}$ ions for the exchangeable cations present on the clay mineral surfaces, which leads to the flocculation of the soil particles due to a decrease in the DDL thickness; and (2) the pozzolanic reactions that lead to the formation of hydrated cementitious products [79]. Whereas the gradual decrease in strength observed at longer soaking periods (14 and 28 days) is ascribed to a 
decrease in pozzolanic activity. This is because the percentage of lime added to the soil sample was below the LSO of the natural soil. In contrast, the pre-leaching CBR values of the LLS samples treated with 7.5 and $10 \mathrm{wt} . \%$ lime increased from $26.1 \%$ to $26.6 \%$ and $28.8 \%$ to $31.4 \%$ after a soaking period of 14 and 28 days, respectively (Figure $8 \mathrm{~b}$ ).
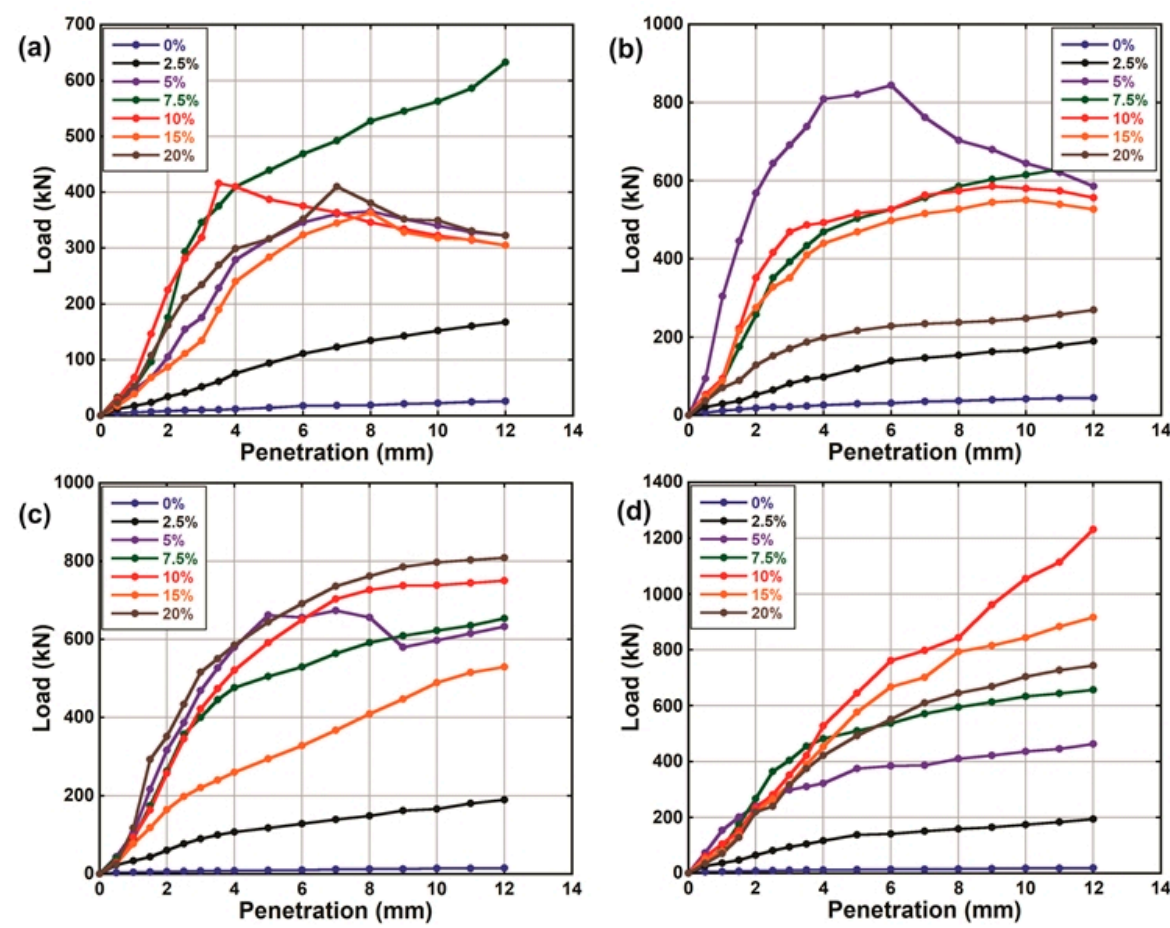

Figure 6. Pre-leaching load-penetration curves of natural soil and lime-lateritic soil samples after a soaking period of (a) 3 (b) 7 (c) 14 and (d) 28 days.
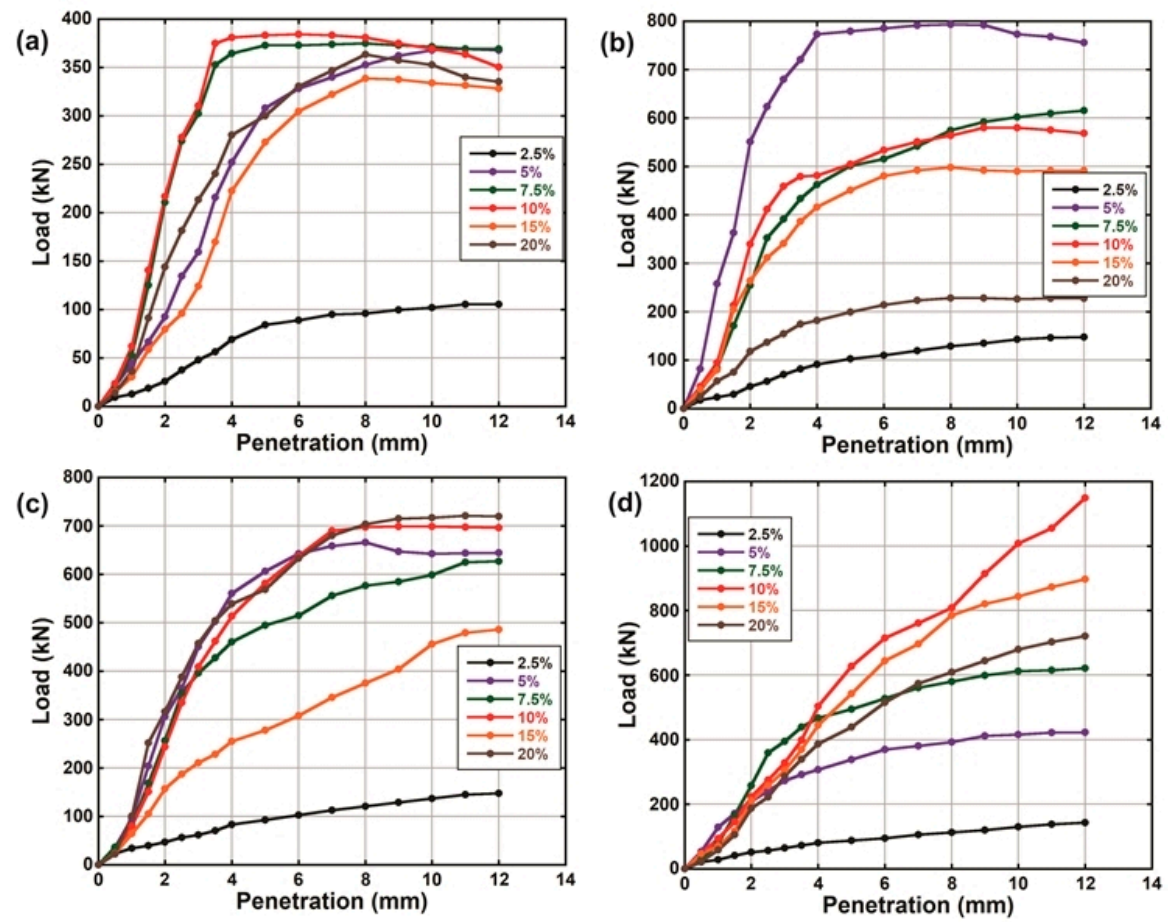

Figure 7. Post-leaching load-penetration curves of natural soil and lime-lateritic soil samples after a soaking period of (a) 3 (b) 7 (c) 14 and (d) 28 days. 

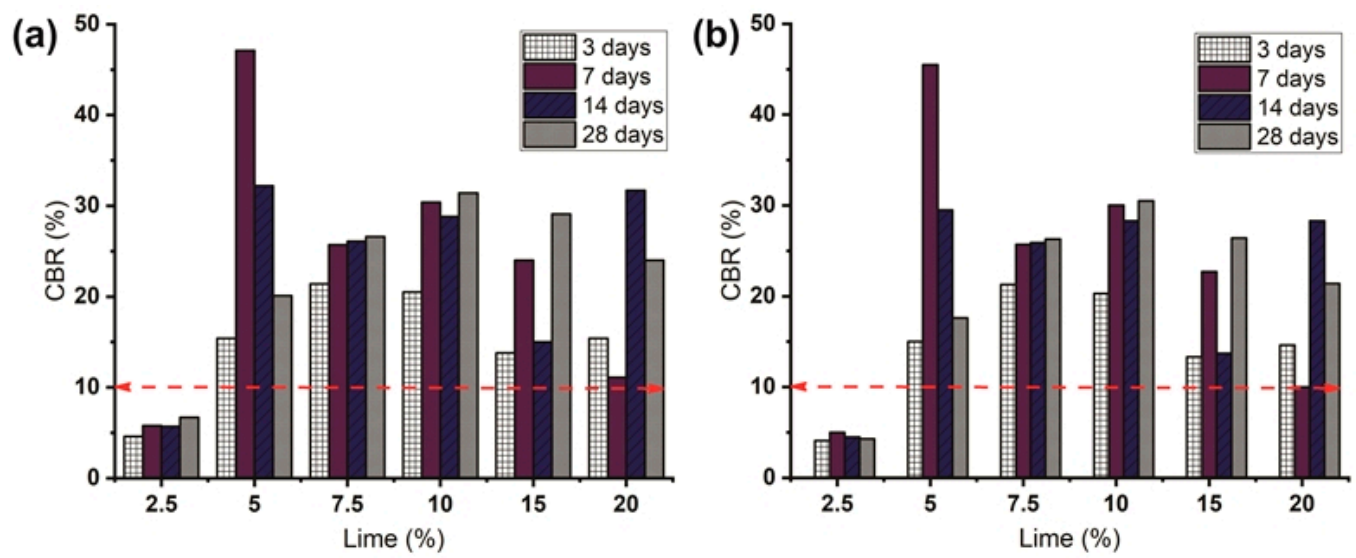

Figure 8. Effect of lime on CBR values of lime-lateritic soil samples at different leaching periods. (a) Pre-leaching CBR values, and (b) Post-leaching CBR values (dashed red lines indicate the minimum soaked CBR value for subgrade in Nigeria according to FMW\&H [78]).

Figure 9 shows the strength reduction indices (SRI) of the LLS samples determined from the pre-leaching and post-leaching CBR values of the natural soil and the LLS samples. The SRI values of the LLS samples at different lime contents and leaching periods were determined as per the equation below:

$$
\mathrm{SRI}=\frac{\mathrm{CBR}_{\mathrm{bl}}-\mathrm{CBR}_{\mathrm{al}}}{\mathrm{CBR}_{\mathrm{bl}}}
$$

where $\mathrm{CBR}_{\mathrm{bl}}=$ pre-leaching and post-soaking CBR value of a representative LLS sample, and $\mathrm{CBR}_{\mathrm{al}}=$ post-leaching $\mathrm{CBR}$ value of the same LLS sample. The analysis was performed to evaluate the durability and engineering behaviour of the LLS samples under continuous water ingress. The results indicate that the LLS sample treated with $2.5 \mathrm{wt} . \%$ lime had the highest SRI value, which increased from 0.11 to 0.36 as the leaching period progressed from three to 28 days. In contrast, the LLS samples treated with 7.5 and $10 \mathrm{wt} . \%$ lime presented the lowest SRI values of 0.01 and 0.03 after a leaching period of 28 days. Further addition of lime to the natural soil led to an increase in the (terminal) SRI values to about 0.09 and 0.11 for the LLS samples treated with 15 and $20 \mathrm{wt} . \%$ lime, respectively. The overall trend of the results demonstrates the high susceptibility of the LLS samples treated with lime below and slightly above the soil's OLC (i.e., 2.5 and $5 \mathrm{wt} . \%$ lime) to leaching-induced deterioration. The trends of the results are consistent with the results obtained by other researchers (e.g., $[55,80,81])$.

\section{4. $p H$}

Figure 10 shows the variation of $\mathrm{pH}$ of the leachate obtained from the natural soil and the LLS samples at different leaching periods. The trend of the result indicates that the $\mathrm{pH}$ of the natural soil was constant at 10.2 as the leaching time progressed from three to 28 days. The addition of various percentages of lime to the natural soil and leaching for a minimum of three days caused the $\mathrm{pH}$ of the lateritic soil to increase from 10.2 to 12.1 and 12.46, which corresponds to the LLS samples treated with 2.5 and $20 \mathrm{wt} . \%$ lime, respectively. Furthermore, the results show a marked decrease in $\mathrm{pH}$ values of the LLS samples as the leaching time increased from 3 to 28 days. The rate of reduction in $\mathrm{pH}$ of the treated soil samples was found to decrease with an increase in lime content. The highest percentage decrease in $\mathrm{pH}(10.7 \%)$ after a leaching period of 28 days was observed in the LLS sample treated with $2.5 \mathrm{wt} . \%$ lime, whereas the percentage decrease in $\mathrm{pH}$ of the soil LLS samples treated with 5, 7.5, 10, 15, and $20 \mathrm{wt} . \%$ lime was 3.3\%, $2.4 \%, 1.6 \%, 1.3 \%$, and $0.8 \%$, respectively. Furthermore, the $\mathrm{pH}$ values of the treated soil samples were above 12 after a leaching period of 28 days, except for the LLS samples treated with 2.5 and $5 \mathrm{wt} . \%$ lime, which had $\mathrm{pH}$ values of 10.8 and 11.9 , respectively, for the same leaching period. 
The gradual decrease in $\mathrm{pH}$ of the pore fluid was due to the leaching of $\mathrm{Ca}^{2+}$ and $\mathrm{OH}^{-}$ ions from the soils, which causes a reduction in the pozzolanic activity. Some researchers (e.g., $[40,68])$ have attributed the highly alkaline nature of the pore fluid to the dissolution of $\mathrm{Ca}^{2+}$ and $\mathrm{OH}^{-}$ions as a result of mixing the soil with $\mathrm{CaO}$ in the presence of water. However, the decrease in $\mathrm{pH}$ of the pore fluid has been ascribed to: (1) the pozzolanic reactions that result in the depletion of soluble calcium concentration, especially at lime contents below the OLC of the soil [33,82], and (2) the removal of lime from the LLS samples under continuous leaching [60]. Similar trends in $\mathrm{pH}$ reduction under continuous curing and leaching have been reported by $[34,61,83]$.

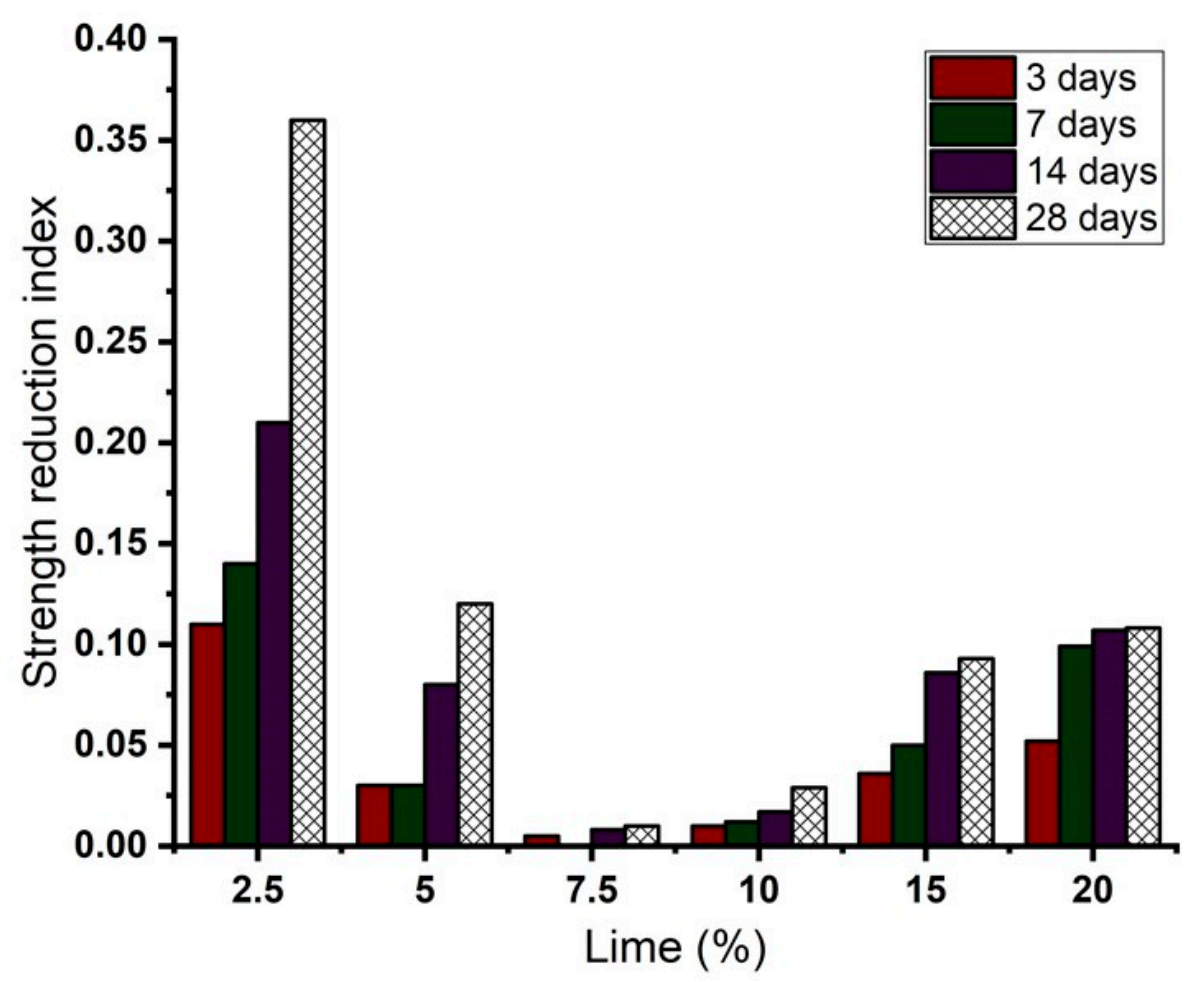

Figure 9. Effect of lime on strength reduction index of lime-lateritic soil samples at different leaching periods.

\subsection{Electrical Conductivity}

Figure 11 shows the variation of EC of the pore fluid as leaching time increased from three to 28 days. According to [33], electrical conductivity (EC) is a physicochemical parameter that can be used to determine the conductivity of solutions and thus is a function of the amount of ions (cations or anions) in the solution. The addition of various amounts of lime to the natural soil and leaching for a minimum of $72 \mathrm{~h}$ (three days) caused the EC value to increase from 8.5 to $10.3,11.4$, and $12.5 \mathrm{mS} / \mathrm{cm}$, for the LLS samples treated with 2.5, 7.5, and 20 wt.\% lime, respectively. The marked increase in EC values of the stabilised soil samples signifies the dissolution of $\mathrm{Ca}(\mathrm{OH})_{2}$ to release calcium and hydroxyl ions [33]. Beyond the 3 days leaching period, the EC values of the stabilised soils decreased considerably as leaching time increased from 7 to 28 days. The low (terminal) EC value of the LLS sample treated with $2.5 \mathrm{wt} . \%$ lime, relative to the LLS samples treated with higher percentages of lime $(5,7.5,10,15$, and $20 \mathrm{wt} . \%$ lime), could be ascribed to (1) the fact that the amount of lime added to the natural soil was significantly below the soil's OLC. Consequently, the concentration of $\mathrm{Ca}^{2+}$ ions in the pore fluid of the soil was significantly insufficient to ensure complete flocculation and agglomeration of the clay fraction in addition to ensuring long-term pozzolanic activity; and (2) the considerable depletion of calcium ions from the pore fluid as a result of continuous leaching. The results further indicate that the EC value of the natural soil slightly decreased from 8.5 to $8.25 \mathrm{mS} / \mathrm{cm}$, 
while the EC values of the LLS samples increased with an increase in lime but generally decreased as the leaching time increased from three to 28 days. Similar trends in EC values have been observed by $[33,34,84]$.

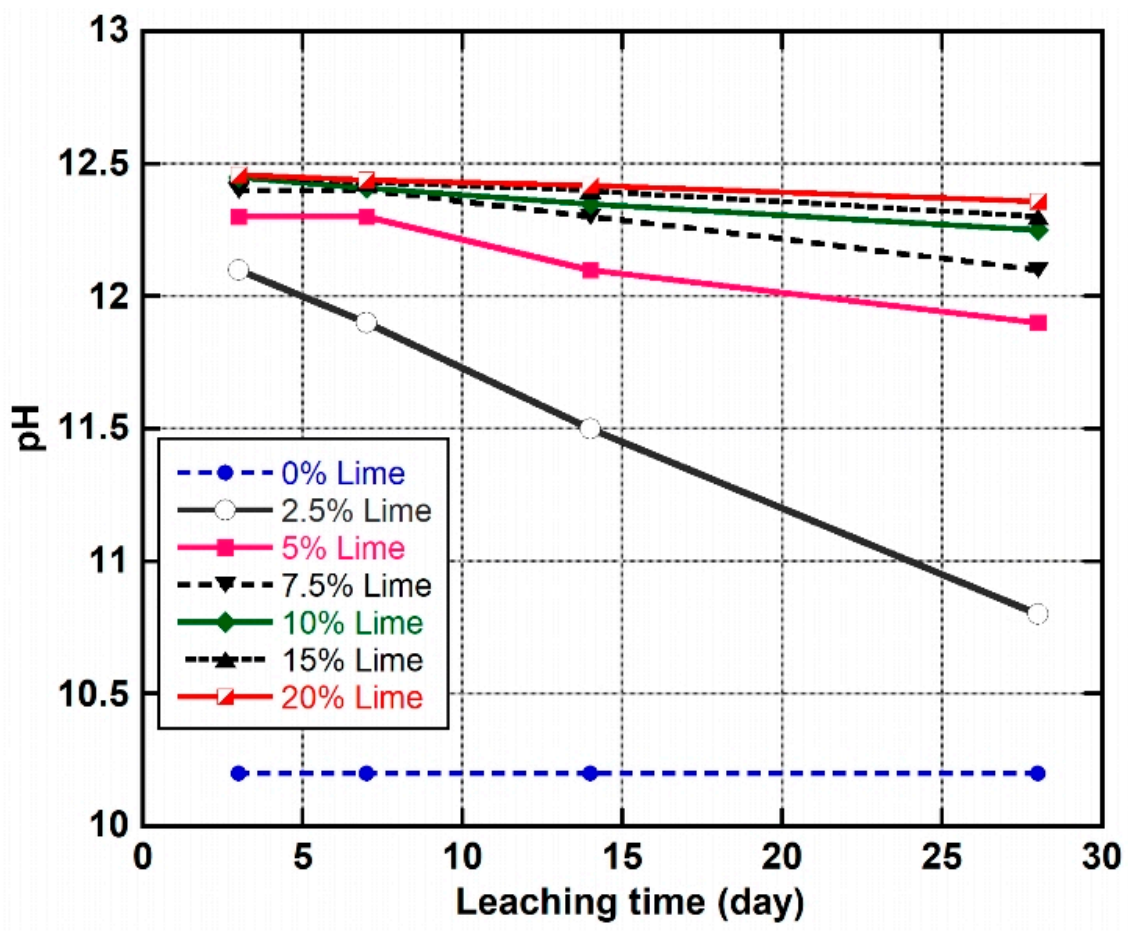

Figure 10. Variations in $\mathrm{pH}$ values of natural soil and lime-lateritic soil samples at different leaching periods.

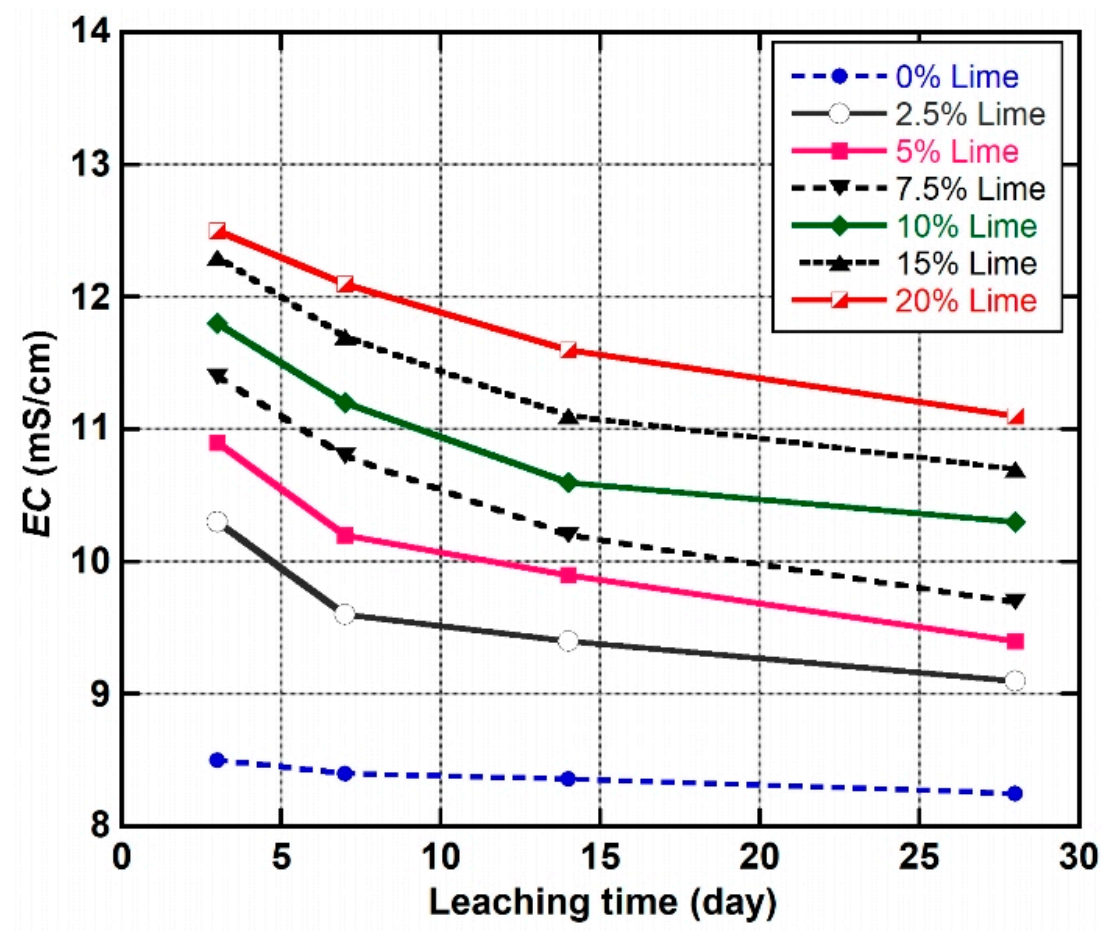

Figure 11. Trends in EC values of natural soil and lime-lateritic soil samples at different leaching periods. 


\subsection{Calcium and Potassium Concentrations}

The trends of calcium concentrations in the leachate of the natural soil and the LLS samples are given in Figure 12. The results reveal a general decrease in calcium concentration in all the leachate, except for the natural soil, where the concentration of calcium varied from 82 to $85 \mathrm{mg} / \mathrm{L}$. Furthermore, the concentrations of calcium in the leachate can be seen to increase with an increase in percentage lime content. The soil specimens treated with 2.5, 5 , and $7.5 \mathrm{wt} . \%$ lime had the lowest concentrations of calcium in their leachate $(195,203$, and $215 \mathrm{mg} / \mathrm{L}$ ), which decreased to 115,135 , and $158 \mathrm{mg} / \mathrm{L}$, as the leaching time progressed from three to 28 days. In contrast, the initial concentration of calcium in the leachate of the soil mixtures treated with 15 and $20 \mathrm{wt} . \%$ lime decreased from 235 and $255 \mathrm{mg} / \mathrm{L}$ to 195 and $220 \mathrm{mg} / \mathrm{L}$ under the same leaching period. It is important to note that the highest and lowest rates of calcium washout were observed in the LLS samples treated with 2.5 and $20 \mathrm{wt} . \%$ lime, which gave a percentage decrease of $41 \%$ and $13 \%$, respectively. This behaviour has been found to occur in soil mixtures dosed with lime at or below the OLC of the natural soil and has been ascribed to the immediate consumption of calcium, given the very low alkaline nature of their pore fluid, which is responsible for enhancing cation exchange and pozzolanic reactions [85]. Conversely, the high amount of $\mathrm{Ca}^{2+}$ ions in the pore fluid of the LLS samples stabilised above the OLC of the lateritic soil is responsible for long-term cation exchange and pozzolanic reactions which produce hydrated cementitious products that cause considerable improvements in strength, stiffness, and durability of the stabilised soil samples.

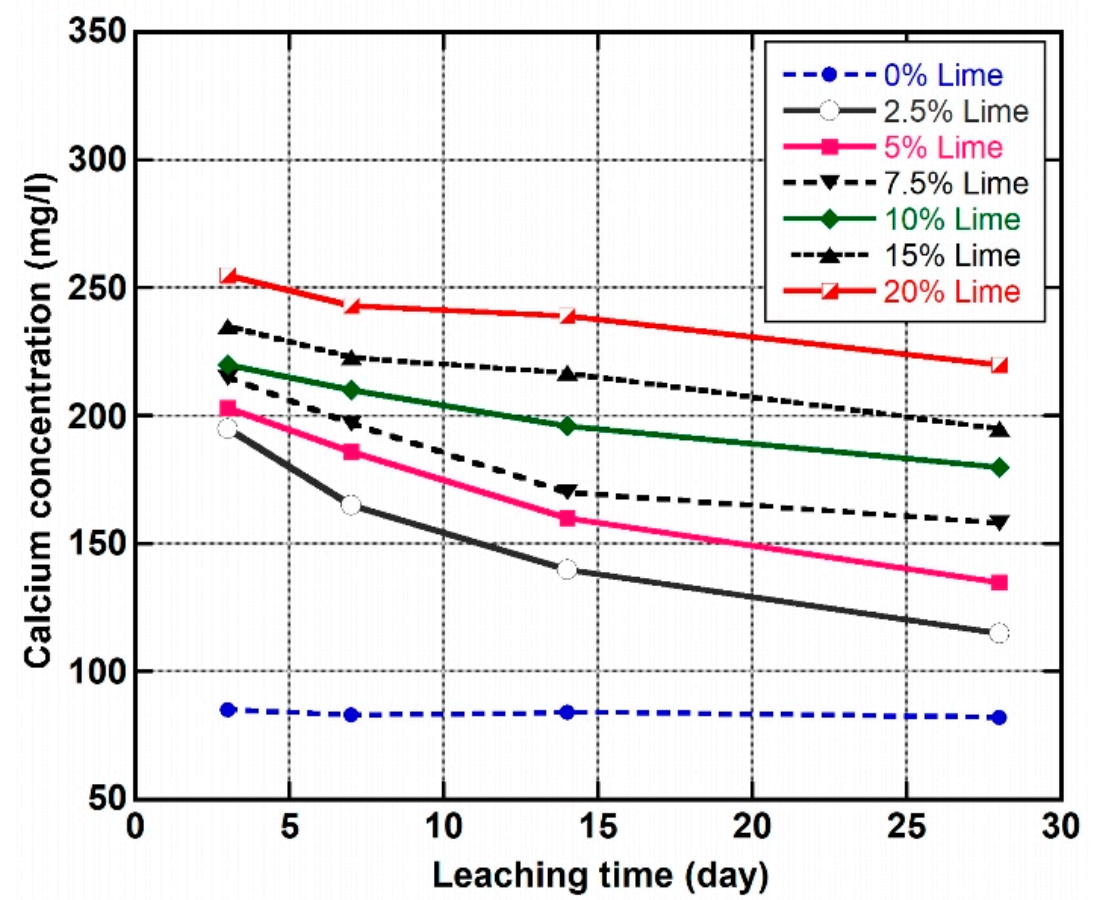

Figure 12. Variations in calcium concentrations in the pore fluid of the natural soil and lime-lateritic soil samples at different leaching periods.

Figure 13 shows the variation of potassium $\left(\mathrm{K}^{+}\right)$concentrations in the leachate of the natural soil and the LLS samples. The results reveal that the concentration of $\mathrm{K}^{+}$ions in the leachate of the LLS samples increased with an increase in lime but decreased as the leaching time progressed from three to 28 days. However, the concentration of $\mathrm{K}^{+}$ions in the leachate of the natural soil increased from 9.6 to $12 \mathrm{mg} / \mathrm{L}$ and subsequently decreased sharply to $1.7 \mathrm{mg} / \mathrm{L}$, as the leaching time progressed from three to 28 days. The high concentration of $\mathrm{K}^{+}$ions in the leachate of the LLS samples stabilised above the OLC of the lateritic soil is attributed to the highly alkaline environment produced by the dissolution of 
$\mathrm{Ca}(\mathrm{OH})_{2}$ to release $\mathrm{Ca}^{2+}$ and $\mathrm{OH}^{-}$ions; this intensified the dissolution of the siliceous and aluminous compounds from the lattices of the clay minerals to release $\mathrm{K}^{+}$ions and other ions such as $\mathrm{Al}^{3+}, \mathrm{Na}^{+}$, and $\mathrm{Si}^{4+}$. These ions then react with $\mathrm{Ca}^{2+}$ cations from the lime to form cementitious products responsible for long-term strength improvements in the LLS soils following the reaction mechanisms as represented by Equations (2)-(5).

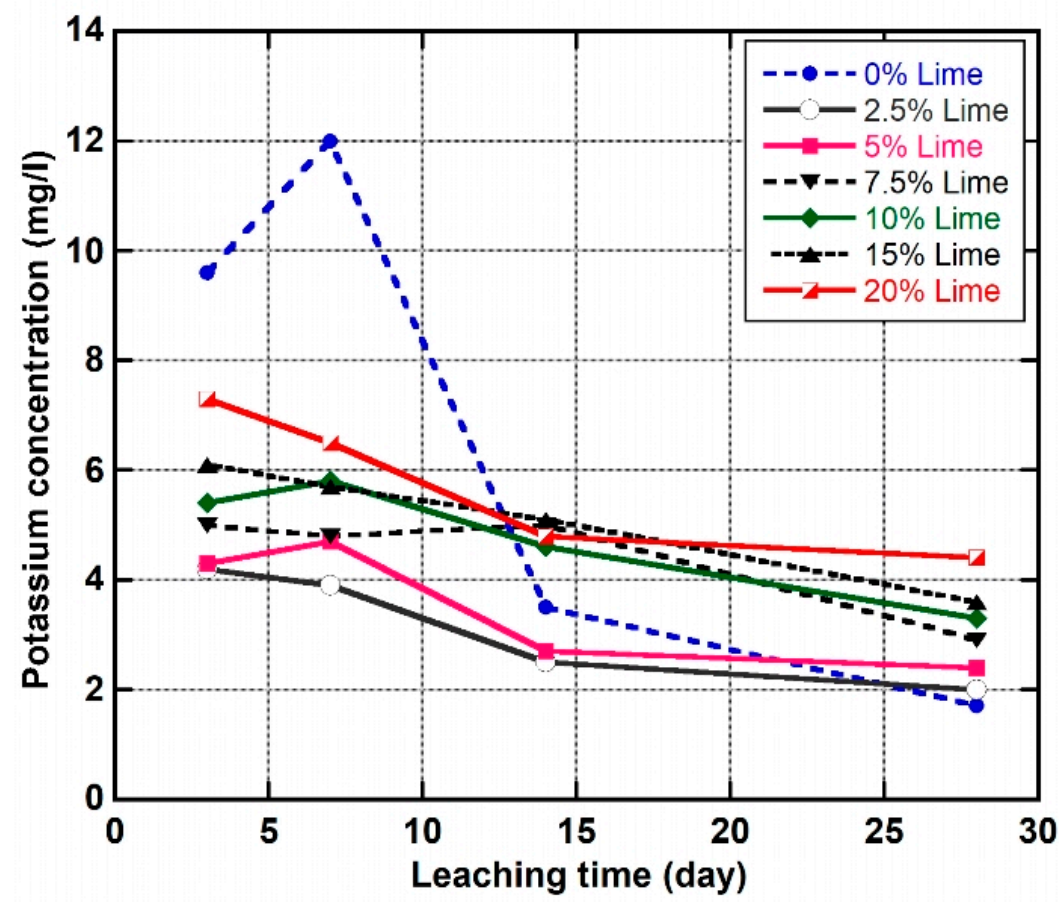

Figure 13. Evolution of potassium concentrations in the pore fluid of the natural soil and lime-lateritic soil samples at different leaching periods.

Step 1: Hydration of quicklime to form calcium hydroxide:

$$
\mathrm{CaO}+2 \mathrm{H}_{2} \mathrm{O} \rightarrow \mathrm{Ca}(\mathrm{OH})_{2}
$$

Step 2: Dissolution of calcium hydroxide to release $\mathrm{Ca}^{2+}$ and $\mathrm{OH}^{-}$ions:

$$
\mathrm{Ca}(\mathrm{OH})_{2} \leftrightarrow \mathrm{Ca}^{2+}+\mathrm{OH}^{-}
$$

Step 3: Formation of C-S-H and C-A-H via pozzolanic reactions:

$$
\begin{aligned}
& \mathrm{Ca}^{2+}+2 \mathrm{OH}^{-}+\mathrm{SiO}_{2} \rightarrow \mathrm{C}-\mathrm{S}-\mathrm{H} \\
& \mathrm{Ca}^{2+}+2 \mathrm{OH}^{-}+\mathrm{Al}_{2} \mathrm{O}_{3} \rightarrow \mathrm{C}-\mathrm{A}-\mathrm{H}
\end{aligned}
$$

\subsection{Microstructural Analysis (Scanning Electron Microscopy)}

Figure 14 shows the photomicrographs of the untreated (natural) soil and the LLS samples retrieved from the mould after a soaking period of 28 days. The SEM micrographs of the soil-lime mixes presented here are only for the 5 and $15 \mathrm{wt} . \%$ lime-treated samples, given that the microfabric and morphology of the treated LLS samples varied slightly as lime content increased from 2.5 to $20 \mathrm{wt} . \%$. The microfabric of the untreated lateritic soil exhibits a honeycomb microstructure, which consists mainly of a mass of discordantly shaped clay particles with sizes ranging from 30 to 150 microns (Figure 14a). The structure is enhanced by the adsorption of colloidal sesquioxide gels on the surface of the clay particles or at the face-to-face and edge-to-face contact points between successive clay 
lamina. The densely-packed and homogeneous nature of the aggregates reveal wedge-like inter-aggregate pores with a few microcracks that run parallel to the orientation of the clay particles, which are similar to the microstructures previously reported by [86-88].
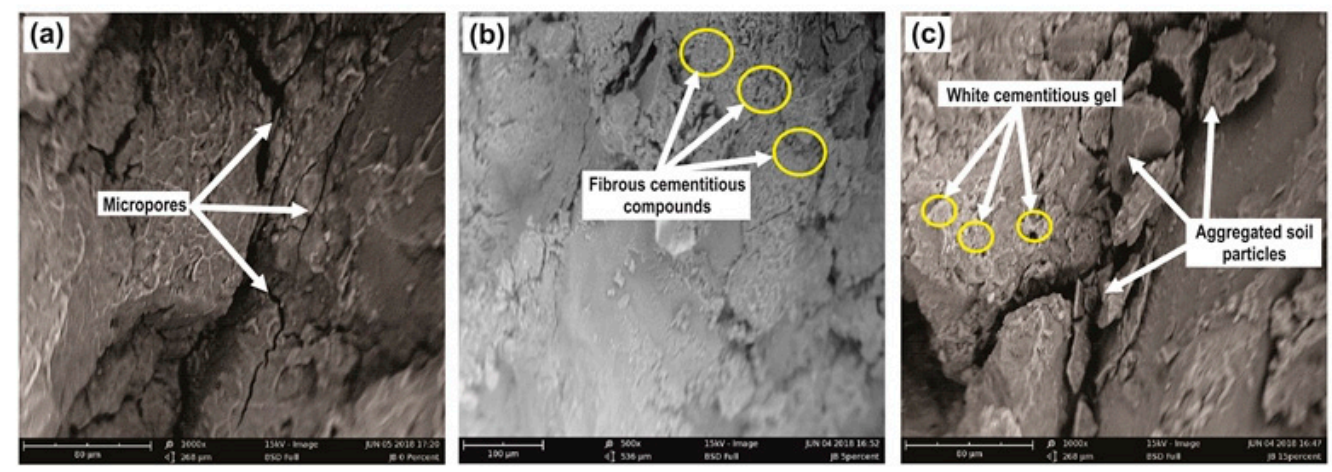

Figure 14. Scanning electron microscope images of (a) natural soil, (b) LLS + 5 wt.\% lime, and (c) LLS $+15 \mathrm{wt}$.\% lime after a soaking period of 28 days.

In contrast, the microfabric and morphology of the LLS samples treated with 5 and $15 \mathrm{wt} . \%$ lime reveal a heterogeneous microstructure, which comprises highly aggregated soil particles that are dispersed in a network of a reticulated fibrous mass of cementitious products. It can be observed that the degree of flocculation and agglomeration of the soil particles and the density of the fibrous compounds were lower in the LLS sample treated with $5 \mathrm{wt} . \%$ lime than in the LLS sample treated with $15 \mathrm{wt} . \%$ lime. The microstructure of the $5 \mathrm{wt} . \%$ LLS sample shows that the closely-knit structure of the untreated soil has improved with the addition of lime, which results in the formation of several clusters of small agglomerates (Figure 14b). The microfabric of the $5 \mathrm{wt} . \%$ LLS sample may demonstrate the rapid depletion of lime $\left(\mathrm{Ca}^{2+}\right.$ ions) from the pore fluid of the soil and the low concentration of $\mathrm{Ca}^{2+}$ ions required for pozzolanic reactions that would result in the production of cementitious binders. This justifies the results obtained from the CBR tests, where the CBR value of the $5 \mathrm{wt} . \%$ LLS sample increased from $15.4 \%$ and reached a maximum value of $47.1 \%$ within seven days of soaking in water. The CBR value then decreased to $20.1 \%$ at the end of the 28 days soaking period, signifying a decrease in the strength and stiffness of the treated soil (cf. Figure 8).

The microfabric of the LLS + $15 \mathrm{wt} . \%$ lime sample reveals a very heterogeneous and highly aggregated matrix with a microstructure that shows a well-cemented morphology (Figure 14c). The morphology, therefore, indicates the disintegration of the bonds between the clay particles and the evolution of medium to large-sized aggregates with clearly visible macropores. Additionally, the cemented morphology further indicates the filling up of any available interstitial pore spaces by the cementitious gels (C-S-H and C-A-H) formed from pozzolanic reactions. This process is increased by the high concentration of $\mathrm{Ca}^{2+}$ ions in the pore fluid of the soil. The high amount $\mathrm{Ca}^{2+}$ ions therefore promotes long-term pozzolanic reactions, which lead to the formation of hydrated cementitious products (C-S-H and C-A-H gels) that generally appear as white patches on the surface of the treated soil.

\subsection{X-ray Diffraction Analysis}

Figure 15 shows the X-ray diffractograms of the (natural) lateritic soil and the LLS samples treated with 5, 10, 15, and $20 \mathrm{wt} . \%$ lime after a leaching period of 3 days. Mineralogical analysis was not carried out on the soil samples at higher soaking periods of 7, 14 and 28 days because it was observed that short- to medium-term leaching periods had an insignificant effect on the mineralogical composition of the LLS samples. The X-ray diffractogram of the natural soil shows that kaolinite and chlorite are the dominant clay minerals in the soil, while quartz and goethite constitute other essential non-clay minerals. The presence of goethite and ferric oxide in the natural lateritic soil confirms its unsuit- 
ability for use as subbase and subgrade layers for the construction of flexible pavements due to the following reasons: (1) goethite acts as a cementing agent in lateritic soils of rhyolite origin, and thus makes lateritic soils susceptible to cracking when subjected to differential stress; and (2) the presence of goethite, hydrated halloysite, allophane and gibbsite in lateritic soils have been attributed to their sensitivity to drying, which causes irreversible changes in their physical properties $[13,89,90]$.

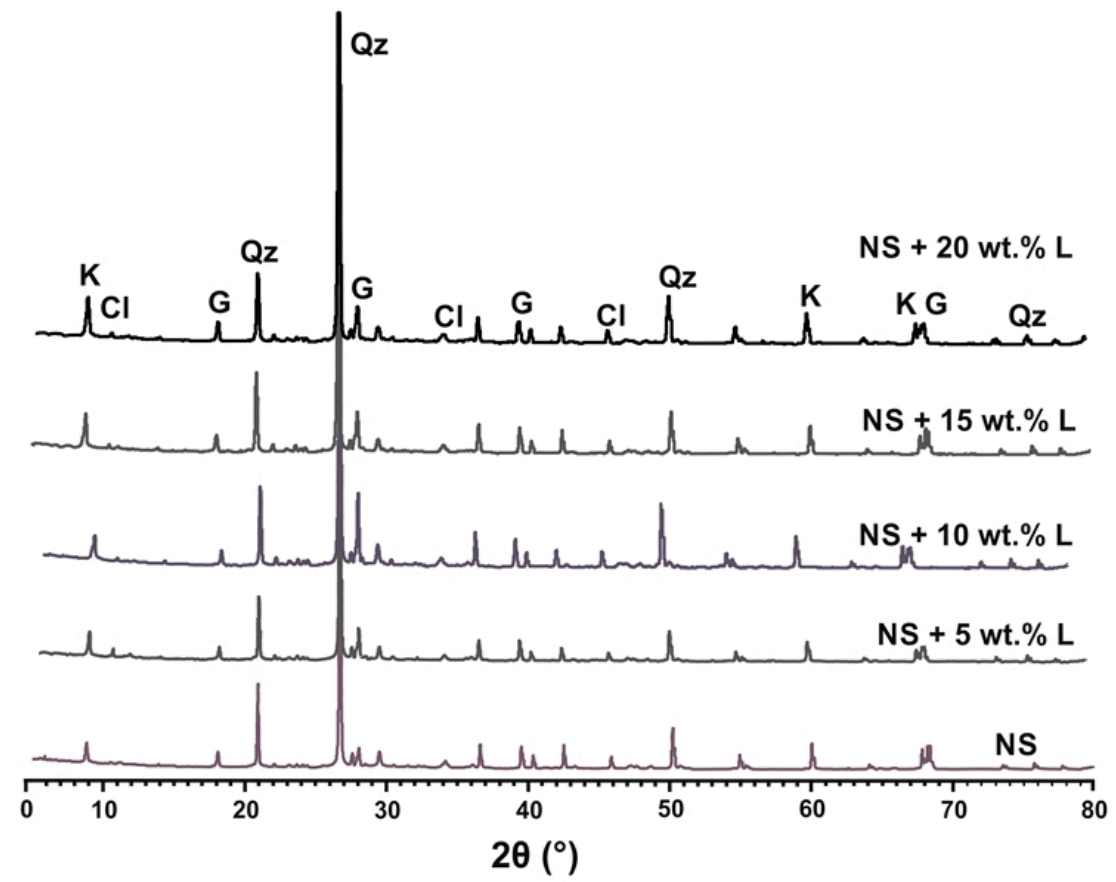

Figure 15. X-ray diffractograms of natural soil and lime-lateritic soil samples admixed with 5, 10, 15, and $20 \mathrm{wt} . \%$ lime after a leaching period of 3 days. ( $N S=$ natural soil, $L=$ lime, $C l=$ chlorite, $G=$ goethite, $K=$ kaolinite, $Q z=$ quartz).

The X-ray diffractograms of the LLS samples reveal a marked reduction in the peak intensities of some of the minerals as lime increased from 5 to $20 \mathrm{wt} . \%$. The slight reduction in the intensities of quartz and kaolinite within the LLS sample treated with 5 wt.\% lime relative to the LLS samples treated with 10, 15, and $20 \mathrm{wt} . \%$ lime demonstrates the rapid depletion of $\mathrm{Ca}^{2+}$ ions from the pore fluid as a result of flocculation-agglomeration reactions that result in the modification of the soil's physical properties. Further decrease in peak intensities of chlorite, kaolinite and quartz was observed with the addition of more lime to the lateritic soil. This may be ascribed to the release of $\mathrm{Si}^{4+}, \mathrm{Al}^{3+}$, and $\mathrm{K}^{+}$ ions due to the dissolution of the clay minerals under a highly alkaline environment, and subsequent pozzolanic reactions which result in the crystallisation of cementitious products. The degree of alteration in the structure of the clay minerals was found to be influenced by the amount of lime added to the lateritic soil.

\section{Discussion}

\subsection{Influence of Water Ingress on the Durability of the Lime-Stabilised Lateritic Soil}

The mechanisms of soil-lime reactions involve a complex process that leads to the modification of the soil via several processes: cation exchange, flocculation-agglomeration, carbonation and pozzolanic reactions. Therefore, the durability of chemically stabilised soils depends on several factors, including the mineralogical and physicochemical constituents of the soil, the amount of chemical additives added to the soil, and several environmental factors. Considerable research has shown that climatic and environmental factors majorly affect the durability and engineering performance of cement- and limestabilised subbase and subgrade materials, leading to the deterioration and reduction in 
the service life of flexible pavements [51,53]. Numerous cases of deterioration in chemically stabilised pavement interlayers and embankments founded on floodplains have been attributed to leaching that removes the stabilising effect of the chemical additives via rainfall-induced water ingress. Similarly, results from previous experimental investigations performed to evaluate the adverse effect of the leaching-induced deterioration of pavement interlayers and earth embankments revealed significant improvements in the durability of soils stabilised significantly above their OLC (e.g., [62,72]). Lime treatment of soil at its OLC improves its workability by causing a reduction in the DDL thickness, which subsequently leads to long-term improvement in the engineering properties of the soil. However, the rate of pozzolanic activity within the soil-lime system is influenced by the $\mathrm{pH}$ of the pore fluid because the highly alkaline nature of the pore fluid amplifies the dissolution of $\mathrm{Al}^{3+}$ and $\mathrm{Si}^{4+}$ ions from the clay minerals.

The decreasing trends of $\mathrm{EC}$ and $\mathrm{pH}$ of the pore fluid after a leaching period of 28 days demonstrate the adsorption and leaching of lime, which leads to a decrease in the concentration of $\mathrm{Ca}^{2+}$ and $\mathrm{OH}^{-}$ions in the pore fluid of the LLS samples. Initially, the addition of quicklime and water to the lateritic soil leads to an increase in the $\mathrm{pH}$ and EC of the pore fluid as $\mathrm{Ca}(\mathrm{OH})_{2}$ dissolves to release $\mathrm{Ca}^{2+}$ and $\mathrm{OH}^{-}$ions. It is noteworthy that the level of alkalinity and EC of the pore fluid depends on the amount of lime added to the natural soil. Before leaching, the rapid adsorption of $\mathrm{Ca}^{2+}$ and $\mathrm{OH}^{-}$ions onto the clay mineral surfaces results in the flocculation-agglomeration of the clay particles which subsequently reduces the plasticity index of the soil (cf. Figures 4 and 10). The rapid reduction in EC and $\mathrm{pH}$ values of the LLS samples treated with lime below and slightly above the soil's OLC under continuous water ingress is closely linked with the leaching of lime from the pore fluid and the alteration of the amorphous or poorly crystallised cementitious products (C-S-H and C-A-S-H). Therefore, the gradual reduction in strength and stiffness of the LLS samples treated with 2.5 and $5 \mathrm{wt} . \%$ lime relative to the LLS samples treated with 7.5 and $10 \mathrm{wt} . \%$ lime is indicative of a decreasing pozzolanic activity due to the reduction in the concentrations of $\mathrm{Ca}^{2+}$ and $\mathrm{OH}^{-}$ions within the soil-lime system (cf. Figures 8 and 12). Furthermore, the high SRI values of 0.36 and 0.12 obtained from the LLS + $2.5 \mathrm{wt} . \%$ lime and LLS + $5 \mathrm{wt} . \%$ lime samples after leaching for 28 days demonstrates that water ingress adversely affected the durability of the soil samples (cf. Figure 9).

In contrast, the high amount of lime in the pore fluid of the LLS samples treated with 7.5 and $10 \mathrm{wt} . \%$ lime contributes to long-term pozzolanic reactions within the highly alkaline environment. The high $\mathrm{pH}$ of the soil-lime system amplifies the crystallisation of C-S-H and C-A-H, thereby causing long-term improvements in strength and stiffness of the treated soil. Indeed, leaching seems to have little effect on the LLS samples treated with lime above the soil's OLC because the highly alkaline nature of the soil-lime system amplifies the release of $\mathrm{Al}^{3+}$ and $\mathrm{Si}^{4+}$ ions from the clay minerals, which subsequently react with $\mathrm{Ca}^{2+}$ ions to form well crystallised cementitious products (cf. Figure 14). Furthermore, the high strength, stiffness, and well-cemented morphology of the LLS + $7.5 \mathrm{wt} . \%$ lime and LLS + $10 \mathrm{wt} . \%$ lime samples, in addition to their low (terminal) SRI values of 0.01 and 0.03 , made them the least likely to deteriorate when subjected to long-term water ingress or exposed to harsh environmental conditions.

\subsection{Practical Engineering Implications}

Improving the durability of lime-stabilised subgrades can significantly reduce the amount of lime required for soil stabilisation and occasional road maintenance, thereby enhancing the sustainable performance of lime-stabilised soils through a significant reduction in the amount of lime used in road maintenance and other activities that increase carbon footprint. The permanency of lime stabilisation is one of the critical factors considered in the design and construction of earth embankments, road pavements and hydraulic barriers (landfill liners) for waste containment purposes. Indeed, the design and construction of road pavements and highway embankments with lime contents above the soil's OLC is vital to mitigating the detrimental effects of pavement distress and for improving their 
service life. The issue of deterioration and unsustainability of pavement interlayers and hydraulic structures treated with lime below their OLC has called for an improvement in the mix design procedure considering the mineralogical characteristics of the soil and other key environmental factors.

The results of this experimental investigation demonstrate that the soil mixtures treated with 7.5 and 10 wt.\% lime had the lowest SRI values. These low SRI values further indicate that stabilising the lateritic soil with $8 \mathrm{wt}$ \% lime would mitigate the adverse effect of leaching via water ingress into the subbase and subgrade layers, thereby improving the durability and service life of pavements founded on floodplains. Similar tests have been carried out by [53] on eight (8) different soil samples stabilised with cement (3 4 wt.\%) and lime (3 8 wt.\%). The authors found that the soil mixtures treated with $6 \mathrm{wt} . \%$ lime retained about $97 \%$ to $98.8 \%$ of their strength after being subjected to 14 cycles of leaching; the authors, therefore, recommended stabilising the soil samples with chemical additives above $6 \mathrm{wt}$ \% to ensure long-term stability. Furthermore, the results of leaching and durability tests carried out by $[62,63]$ on a silty soil stabilised with 1 and 3 wt.\% lime indicated a considerable decrease in strength $(\sim 85 \%)$ in the soil treated with $1 \mathrm{wt} . \%$ lime. Mechanistic-empirical (M-E) pavement design carried out by [72] on a clay soil treated with varying percentages of lime and waste ceramic dust (WCD) observed that the mixture treated with $10 \mathrm{wt}$.\% lime (i.e., an additional $6 \mathrm{wt} . \%$ lime above the soil's OLC) had the lowest interlayer thickness and total cost of $393.7 \mathrm{~mm}$ and $\$ 20.2$ million, respectively. In contrast, the mixture treated with $4.5 \mathrm{wt} . \%$ lime $+1.5 \mathrm{wt} . \% \mathrm{WCD}$ requires an interlayer thickness of $635 \mathrm{~mm}$ with cost totalling up to $\$ 23.6$ million.

In summary, leaching-induced deterioration of pavement structures and hydraulic barriers is less likely in lateritic soils treated with lime significantly above their OLC and slightly above their LSO. At these lime contents, the high concentration of $\mathrm{Ca}^{2+}$ ions in the soil-lime system coupled with the availability of $\mathrm{Al}^{3+}$ and $\mathrm{Si}^{4+}$ ions from the clay minerals promotes long-term pozzolanic reactions. These reactions produce hydrated cementitious products that modify the soil matrix by filling up any available interstitial pore spaces, which reduces water ingress and thus increases the resilient modulus of the soil.

\section{Conclusions}

This study investigated the influence of continuous water ingress on the durability and physicochemical behaviour of lime-stabilised lateritic soil. To achieve the aim of the research, the lateritic soil was treated with lime in quantities $(0,2.5,5,7.5,10,15$, and $20 \mathrm{wt} . \%$ ) that were below and above its OLC. Column leaching tests were conducted in two leaching cells to simulate rainfall-induced water ingress into pavement structural layers and its effect on the durability of lime-stabilised lateritic soil. Based on the experimental results, the following conclusions can be drawn:

- Significant improvements in the workability of the LLS samples were obtained by treating the lateritic soil with lime in quantities that were above the soil's OLC of $4 \%$. For instance, the addition of $5 \mathrm{wt}$.\% lime to the lateritic soil resulted in an optimum reduction of the plasticity index of the soil (PI =5\%). However, further increase in lime content above $5 \mathrm{wt}$ \% caused both the soil's liquid limit and plastic limit to increase with a corresponding increase in lime content. This behaviour, which is commonly observed in silica-rich residual soils, has been attributed to the high amount of C-S-H gel produced by the reaction of lime with silica. Consequently, the C-S-H gel adversely affects the plasticity index of the soil due to its high affinity for water.

- $\quad$ CBR test results showed substantial improvements in the engineering properties of the LLS samples as the soaking time increased from 3 to 28 days. This improvement were ascribed to the slow pozzolanic reactions that produced cementitious gels responsible for binding the soil particles together, except for the LLS sample treated with $5 \mathrm{wt} \%$ which showed a substantial decrease in CBR after attaining a peak value of $47.1 \%$ after a soaking period of seven days. 
- The EC values of the LLS samples showed a positive correlation with lime but generally decreased as the leaching time increased from three to 28 days. Similarly, $\mathrm{pH}$ values obtained from the leachate of the LLS samples decreased with an increase in leaching time but increased as lime increased from 0 to $20 \mathrm{wt} . \%$. The leachate of the LLS samples were all above $12.0(\mathrm{pH} \geq 12.0)$ at the end of a leaching period of 28 days, except for the LLS sample treated with $2.5 \mathrm{wt} . \%$ lime which had a pH of 10.8 at the end of the same leaching period.

- The durability and engineering properties of the LLS samples are closely related to their respective $\mathrm{EC}$ and $\mathrm{pH}$ values. Hence, the dissolution of the octahedral and tetrahedral sheets from the aluminosilicate constituents of the clay minerals, which occurs at higher EC and $\mathrm{pH}$ values, favours pozzolanic reactions that produce hydrated cementitious products responsible for improving the strength and stiffness of the lime-stabilised soil.

- Leaching tests conducted on the LLS samples showed that calcium and potassium concentrations increased with an increase in lime but decreased as leaching time increased from 3 to 28 days. Furthermore, minimum and maximum cation concentrations were observed at lime contents below and above the OLC of the soil.

- Results obtained from SEM and XRD analyses revealed that lime addition made the microfabric of the LLS samples to be very heterogeneous and aggregated, with a well-cemented morphology that signifies improvements in strength and stiffness of the soil mixtures. Similarly, the decrease in the peak intensities of chlorite, kaolinite and quartz was attributed to cation exchange and pozzolanic reactions.

- The LLS samples treated with 2.5 and $5 \mathrm{wt} . \%$ lime are not suitable for use as subgrade material because leaching caused adverse changes in their engineering properties, irrespective of the fact that the $5 \mathrm{wt}$.\% LLS sample was treated with lime slightly above the soil's OLC. This is because the amount of lime added to the soil mixtures was significantly below the LSO of the natural soil. Consequently, the leaching of calcium from the LLS samples could be related to the increase in the permeability of the soil as a result of the predominant effect of cation exchange and flocculation-agglomeration reactions. In contrast, leaching did not cause any obvious change in the durability of the LLS samples treated with 7.5 and $10 \mathrm{wt} . \%$ lime due to the high concentration of calcium that enhanced pozzolanic reactions.

- The adverse effect of lime on the strength and stiffness of the LLS samples treated with 15 and $20 \mathrm{wt} . \%$ lime tends to decrease with an increase in leaching time. This behaviour is strongly linked to the leaching of the viscous C-S-H gel and other waterholding gelatinous compounds formed as a result of the mid- to long-term pozzolanic reactions. Therefore, extensive leaching has the potential to decrease the high volume of gel water adsorbed between the solid particles of the hydration products thereby leading to a reduction in the liquid limit, and subsequent increase in strength and stiffness of the LLS samples.

The results of this research highlight the significance of lime stabilisation of lateritic soils and expansive clays above their OLC and at their LSO, to minimise the detrimental effects of leaching-induced deterioration of highway pavements founded on seasonally flooded tropical environments. The lateritic soil used in this study is characteristic of residual soils found within Ogun State, (southwestern) Nigeria, which has specific physicochemical properties that may vary with lateritic soils of other regions. Therefore, a comparative study is necessary to evaluate the different mechanical characteristics and durability of lime-stabilised lateritic soils subjected to continuous water ingress. Furthermore, additional research needs to be carried out using acidified water and deionised water as leaching fluid and extending the leaching time to 365 days to examine the influence of leaching fluid and extended leaching time on the durability of the stabilised soil.

Author Contributions: Conceptualization, Methodology, Resources, Data curation, Validation, Supervision, Project administration, Writing-original draft preparation: [C.O.; S.A.], Investigation, 
Resources, Data curation, Visualization: [A.J.], Data curation, Validation, Supervision, WritingReview \& Editing: [C.O.; S.A.], Writing—Review \& Editing [E.E.], Validation and Supervision [J.O.], Data curation, Validation, Supervision, Writing-Review \& Editing: [S.N.; M.U.], Visualization, Project administration, Validation, Supervision, Writing-Review \& Editing: [T.A.]. All authors have read and agreed to the published version of the manuscript.

Funding: This research received no external funding.

Institutional Review Board Statement: Not applicable.

Informed Consent Statement: Not applicable.

Data Availability Statement: Data is contained within the article.

Acknowledgments: The authors are grateful to the Covenant University Center for Research, Innovation and Development (CUCRID) for providing an enabling environment conducive for academic research. Messrs. I. Ojuawo, K.S. Ayegbo and G. Olimaro of the Geotechnical, Highway and Environmental Engineering laboratories of Covenant University Ota, Nigeria are gratefully acknowledged for their technical assistance.

Conflicts of Interest: The authors declare no conflict of interest.

\section{References}

1. Abam, T.K.S.; Osadebe, C.C.; Omange, G.N. Influence of geology on pavement performance: A case study of Shagamu-Benin City Road, southwestern Nigeria. Glob. J. Geol. Sci. 2005, 3, 17-24. [CrossRef]

2. Charlier, R.; Hornych, P.; Sršen, M.; Hermansson, Å.; Bjarnason, G.; Erlingsson, S.; Pavšič, P. Water influence on bearing capacity and pavement performance: Field observations. In Water in Road Structures; Springer: Dordrecht, The Netherlands, 2009 ; pp. 175-192. [CrossRef]

3. Daniel, J.S.; Jacobs, J.M.; Douglas, E.; Mallick, R.B.; Hayhoe, K. Impact of climate change on pavement performance: Preliminary lessons learned through the infrastructure and climate network (ICNet). In Climatic Effects on Pavement and Geotechnical Infrastructure; American Society of Civil Engineers: Reston, VA, USA, 2014; pp. 1-9. [CrossRef]

4. Elshaer, M.; Daniel, J.S. Impact of pavement layer properties on the structural performance of inundated flexible pavements. Transp. Geotech. 2018, 16, 11-20. [CrossRef]

5. Bhuyan, H.; Scheuermann, A.; Bodin, D.; Becker, R. Soil moisture and density monitoring methodology using TDR measurements. Int. J. Pavement Eng. 2018, 21, 1-12. [CrossRef]

6. Stoner, A.M.; Daniel, J.S.; Jacobs, J.M.; Hayhoe, K.; Scott-Fleming, I. Quantifying the impact of climate change on flexible pavement performance and lifetime in the United States. Transp. Res. Rec. 2019, 2673, 110-122. [CrossRef]

7. Qiao, Y.; Santos, J.; Stoner, A.M.; Flinstch, G. Climate change impacts on asphalt road pavement construction and maintenance: An economic life cycle assessment of adaptation measures in the State of Virginia, United States. J. Ind. Ecol. 2020, $24,342-355$. [CrossRef]

8. Montoya-Alcaraz, M.; Mungaray-Moctezuma, A.; García, L. Sustainable Road Maintenance Planning in Developing Countries Based on Pavement Management Systems: Case Study in Baja California, México. Sustainability 2020, 12, 36. [CrossRef]

9. Huber, S.; Henzinger, C.; Heyer, D. Influence of water and frost on the performance of natural and recycled materials used in unpaved roads and road shoulders. Transp. Geotech. 2020, 100305. [CrossRef]

10. Hasnayn, M.M.; McCarter, W.J.; Woodward, P.K.; Connolly, D.P. Railway subgrade performance after repeated flooding-Largescale laboratory testing. Transp. Geotech. 2020, 23, 100329. [CrossRef]

11. Camacho-Garita, E.; Aguiar-Moya, J.P.; Ávila-Esquivel, T.; Loría-Salazar, L.G. Effect of Moisture on Full-Scale Pavement Distress. J. Test. Eval. 2020, 48, 235-246. [CrossRef]

12. Goswami, R.K.; Mahanta, C. Leaching characteristics of residual lateritic soils stabilised with fly ash and lime for geotechnical applications. Waste Manag. 2007, 27, 466-481. [CrossRef]

13. Gidigasu, M. Laterite Soil Engineering: Pedogenesis and Engineering Principles; Elsevier: Amsterdam, The Netherlands, $2012 ;$ Volume 9.

14. Ghosh, S.; Guchhait, S.K. Geochemical Properties and Lateritization Processes. In Laterites of the Bengal Basin; Springer: Cham, Switzerland, 2020; pp. 83-94. [CrossRef]

15. Sani, J.E.; Yohanna, P.; Chukwujama, I.A. Effect of rice husk ash admixed with treated sisal fibre on properties of lateritic soil as a road construction material. J. King Saud Univ. Eng. Sci. 2020, 32, 11-18. [CrossRef]

16. Morin, W.J.; Todor, P.C. Laterite and lateritic soils and other problem soils of the tropics. In an Engineering Evaluation and Highway Design Study for United State Agency for International Development; AID/csd 3682-1; Lyon Associates Inc.: Baltimore, MD, USA, 1975.

17. De Carvalho, J.C.; de Rezende, L.R.; Cardoso, F.B.D.F.; de Fllucena, L.C.; Guimarães, R.C.; Valencia, Y.G. Tropical soils for highway construction: Peculiarities and considerations. Transp. Geotech. 2015, 5, 3-19. [CrossRef]

18. Paige-Green, P.; Pinard, M.N.; Etterberg, F. A review of specifications for lateritic materials for low volume roads. Transp. Geotech. 2015, 5, 86-98. [CrossRef] 
19. Eyo, E.U.; Ng'ambi, S.; Abbey, S.J. Effect of intrinsic microscopic properties and suction on swell characteristics of compacted expansive clays. Transp. Geotech. 2019, 18, 124-131. [CrossRef]

20. Madu, R.M. An investigation into the geotechnical and engineering properties of some laterites of Eastern Nigeria. Eng. Geol. 1977, 11, 101-125. [CrossRef]

21. Ogbuagu, F.U.; Okeke, C.A.U. Geotechnical properties of lateritic soil from Nimo and Nteje areas of Anambra State, Southeastern Nigeria. IOP Conf. Ser. Mater. Sci. Eng. 2019, 640, 012078. [CrossRef]

22. De Freitas, J.B.; de Rezende, L.R.; de FNGitirana, G., Jr. Prediction of the resilient modulus of two tropical subgrade soils considering unsaturated conditions. Eng. Geol. 2020, 270, 105580. [CrossRef]

23. Ola, S.A. The potentials of lime stabilization of lateritic soils. Eng. Geol. 1977, 11, 305-317. [CrossRef]

24. Akoto, B.K.A.; Singh, G. Some geotechnical properties of a lime-stabilized laterite containing a high proportion of aluminium oxide. Eng. Geol. 1981, 17, 185-199. [CrossRef]

25. Osula, D.O. Lime modification of problem laterite. Eng. Geol. 1991, 30, 141-154. [CrossRef]

26. Omotosho, O.; Eze-Uzomaka, O.J. Optimal stabilisation of deltaic laterite. J. South Afr. Inst. Civ. Eng. 2008, 50, 10-17.

27. Millogo, Y.; Morel, J.C.; Traoré, K.; Ouedraogo, R. Microstructure, geotechnical and mechanical characteristics of quicklimelateritic gravels mixtures used in road construction. Constr. Build. Mater. 2012, 26, 663-669. [CrossRef]

28. Jha, A.K.; Sivapullaiah, P.V. Mechanism of improvement in the strength and volume change behavior of lime stabilized soil. Eng. Geol. 2015, 198, 53-64. [CrossRef]

29. Abbey, S.J.; Eyo, E.U.; Oti, J.; Amakye, S.Y.; Ngambi, S. Mechanical Properties and Microstructure of Fibre-Reinforced Clay Blended with By-Product Cementitious Materials. Geosciences 2020, 10, 241. [CrossRef]

30. Abbey, S.J.; Olubanwo, A.O.; Ngambi, S.; Eyo, E.U.; Adeleke, B. Effect of Organic Matter on Swell and Undrained Shear Strength of Treated Soils. J. Civ. Constr. Environ. Eng. 2019, 4, 48-58. [CrossRef]

31. Abbey, S.J.; Eyo, E.U.; Ng'ambi, S. Swell and microstructural characteristics of high-plasticity clay blended with cement. Bull. Eng. Geol. Environ. 2019, 79, 2119-2130. [CrossRef]

32. Eyo, E.U.; Ngambi, S.; Abbey, S.J. Investigative study of behaviour of treated expansive soil using empirical correlations. In Proceedings of the International Foundation Congress and Equipment Expo, Orlando, FL, USA, 5-10 March 2018; pp. 373-384.

33. Boardman, D.I.; Glendinning, S.; Rogers, C.D.F. Development of stabilisation and solidification in lime-clay mixes. Geotechnique 2001, 51, 533-543. [CrossRef]

34. Rao, S.M.; Shivananda, P. Role of curing temperature in progress of lime-soil reactions. Geotech. Geol. Eng. 2005, 23, 79. [CrossRef]

35. Aldaood, A.; Bouasker, M.; Al-Mukhtar, M. Effect of long-term soaking and leaching on the behaviour of lime-stabilised gypseous soil. Int. J. Pavement Eng. 2015, 16, 11-26. [CrossRef]

36. Hilt, G.H.; Davidson, D.T. Lime Fixation in Clayey Soils. In Highway Research Board Bulletin; National Academy of Sciences: Washington, DC, USA, 1960; Available online: https://trid.trb.org/view/122475 (accessed on 10 October 2020).

37. Diamond, S.; Kinter, E.B. Mechanisms of soil-lime stabilization. Highw. Res. Rec. 1965, 92, 83-102. Available online: https: / / onlinepubs.trb.org/onlinepubs/hrr/1965/92/92-006.pdf (accessed on 10 October 2020).

38. Eades, J.L.; Grim, R.E. A Quick Test to Determine Lime Requirements for Lime Stabilization. In Highway Research Record 139; National Research Council: Washington, DC, USA, 1966; Available online: http:/ / onlinepubs.trb.org/Onlinepubs/hrr/1966/139 /139-005.pdf (accessed on 10 October 2020).

39. Dash, S.K.; Hussain, M. Lime stabilization of soils: Reappraisal. J. Mater. Civ. Eng. 2011, 24, 707-714. [CrossRef]

40. Cherian, C.; Arnepalli, D.N. A critical appraisal of the role of clay mineralogy in lime stabilization. Int. J. Geosynth. Ground Eng. 2015, 1, 8. [CrossRef]

41. Eyo, E.U.; Ng'ambi, S.; Abbey, S.J. Performance of clay stabilized by cementitious materials and inclusion of zeolite/alkaline metals-based additive. Transp. Geotech. 2020, 23, 100330. [CrossRef]

42. Eyo Ng'ambi, S.; Abbey, S.J. An overview of soil-water characteristic curves of stabilised soils and their influential factors. J. King Saud Univ. Eng. Sci. 2020, in press. [CrossRef]

43. Eyo, E.U.; Ng'ambi, S.; Abbey, S.J. Incorporation of a nanotechnology-based additive in cementitious products for clay stabilisation. J. Rock Mech. Geotech. Eng. 2020, 12, 1056-1069. [CrossRef]

44. Eyo, E.U.; Abbey, S.J.; Ngambi, S.; Ganjian, E.; Coakley, E. Incorporation of a nanotechnology-based product in cementitious binders for sustainable mitigation of sulphate-induced heaving of stabilised soils. Eng. Sci. Technol. Int. J. 2020, in press. [CrossRef]

45. Oti, J.E.; Kinuthia, J.M. Lime stabilised glacial till clay incorporating wheat straw or waste tyre rubber granules. In Soil Stabilization: Types, Methods and Applications; Nova Science Publishers, Inc.: New York, NY, USA, 2017; pp. 339-353.

46. Oti, J.E.; Kinuthia, J.M. The Development of Stabilised Clay-Hemp Building Material for Sustainability and Low Carbon Use. J. Civ. Eng. Constr. 2020, 9, 205-214. [CrossRef]

47. Abbey, S.J.; Ngambi, S.; Olubanwo, A.O. Effect of overlap distance and chord angle on performance of overlapping soil-cement columns. Int. J. Civ. Eng. Technol. 2017, 8, 627-637.

48. Eyo, E.U.; Ngambi, S.; Abbey, S.J. Investigative modelling of behaviour of expansive soils improved using soil mixing technique. Int. J. Appl. Eng. Res. 2017, 12, 3828-3836.

49. Zhang, Y.; Johnson, A.E.; White, D.J. Freeze-thaw performance of cement and fly ash stabilized loess. Transp. Geotech. 2019, 21, 100279. [CrossRef] 
50. Hoyos, L.R.; Laikram, A.; Puppala, A.J. Assessment of seasonal effects on engineering behavior of chemically treated sulfate-rich expansive clay. In Expansive Soils—Recent Advances in Characterization and Treatment; CRC Press: Boca Raton, FL, USA, 2006 ; pp. 483-503.

51. Consoli, N.C.; Carretta, M.S.; Leon, H.B.; Schneider, M.E.B.; Reginato, N.C.; Carraro, J.A.H. Behaviour of cement-stabilised silty sands subjected to harsh environmental conditions. Proc. Inst. Civ. Eng. Geotech. Eng. 2020, 1-9. [CrossRef]

52. Le Runigo, B.; Cuisinier, O.; Cui, Y.J.; Ferber, V.; Deneele, D. Impact of initial state on the fabric and permeability of a lime-treated silt under long-term leaching. Can. Geotech. J. 2009, 46, 1243-1257. [CrossRef]

53. Chittoori, B.C.; Puppala, A.J.; Wejrungsikul, T.; Hoyos, L.R. Experimental studies on stabilized clays at various leaching cycles. J. Geotech. Geoenviron. Eng. 2013, 139, 1665-1675. [CrossRef]

54. Hunter, D. Lime-induced heave in sulfate-bearing clay soils. J. Geotech. Eng. 1988, 114, 150-167. [CrossRef]

55. Obuzor, G.N.; Kinuthia, J.M.; Robinson, R.B. Soil stabilisation with lime-activated-GGBS-A mitigation to flooding effects on road structural layers/embankments constructed on floodplains. Eng. Geol. 2012, 151, 112-119. [CrossRef]

56. Chittoori, B.C.; Mishra, D.; Islam, K.M. Forensic investigations into recurrent pavement heave from underlying expansive soil deposits. Transp. Res. Rec. 2018, 2672, 118-128. [CrossRef]

57. Okeke, C.A.U.; Johnson, A.O.; Ogbuagu, F.U.; Akinmusuru, J.O. Effects of continuous leaching on engineering properties of lime-stabilized lateritic soils. IOP Conf. Ser. Mater. Sci. Eng. 2019, 640, 012084. [CrossRef]

58. Okeke, C.A.U.; Ifediniru, C.; Adeyanju, E.; Ede, A.N. The stability analysis of a highway embankment founded on lime-stabilized soft soils in Calabar, Southeast Nigeria. IOP Conf. Ser. Mater. Sci. Eng. 2019, 640, 012103. [CrossRef]

59. McCallister, L.D.; Petry, T.M. Physical property changes in a lime-treated expansive clay caused by leaching. Transp. Res. Rec. 1991, 1295. Available online: https:/ / trid.trb.org/view/359113 (accessed on 12 October 2020).

60. McCallister, L.D.; Petry, T.M. Leach tests on lime-treated clays. Geotech. Test. J. 1992, 15, 106-114. [CrossRef]

61. Khattab, S.A.; Al-Mukhtar, M.; Fleureau, J.M. Long-term stability characteristics of a lime-treated plastic soil. J. Mater. Civ. Eng. 2007, 19, 358-366. [CrossRef]

62. Le Runigo, B.; Ferber, V.; Cui, Y.J.; Cuisinier, O.; Deneele, D. Performance of lime-treated silty soil under long-term hydraulic conditions. Eng. Geol. 2011, 118, 20-28. [CrossRef]

63. Deneele, D.; Le Runigo, B.; Cui, Y.J.; Cuisinier, O.; Ferber, V. Experimental assessment regarding leaching of lime-treated silt. Constr. Build. Mater. 2016, 112, 1032-1040. [CrossRef]

64. Puppala, A.J. Advances in ground modification with chemical additives: From theory to practice. Transp. Geotech. 2016, 9, 123-138. [CrossRef]

65. ASTM D6913/D6913M-17. Standard Test Methods for Particle-Size Distribution (Gradation) of Soils Using Sieve Analysis; ASTM International: West Conshohocken, PA, USA, 2017; Available online: https:/ / www.astm.org/Standards/D6913 (accessed on 12 October 2020).

66. ASTM D7928-17. Standard Test Method for Particle-Size Distribution (Gradation) of Fine-Grained Soils Using the Sedimentation (Hydrometer) Analysis; ASTM International: West Conshohocken, PA, USA, 2017; Available online: https://www.astm.org/ Standards/D7928.htm (accessed on 12 October 2020).

67. ASTM D6276-19. Standard Test Method for Using $p H$ to Estimate the Soil-Lime Proportion Requirement for Soil Stabilization; ASTM International: West Conshohocken, PA, USA, 2019; Available online: https:/ /www.astm.org/Standards/D6276.htm (accessed on 12 October 2020).

68. Bell, F.G. Lime stabilization of clay minerals and soils. Eng. Geol. 1996, 42, 223-237. [CrossRef]

69. ASTM D4318-17e1. Standard Test Methods for Liquid Limit, Plastic Limit, and Plasticity Index of Soils; ASTM International: West Conshohocken, PA, USA, 2017; Available online: https:/ / www.astm.org/Standards/D4318.htm (accessed on 14 October 2020).

70. ASTM D698-12e2. Standard Test Methods for Laboratory Compaction Characteristics of Soil Using Standard Effort (12,400 ft-lbf/ft3 (600 kN-m/m3)); ASTM International: West Conshohocken, PA, USA, 2012; Available online: https://www.astm.org/Standards/D698 (accessed on 14 October 2020).

71. ASTM D1883-16. Standard Test Method for California Bearing Ratio (CBR) of Laboratory-Compacted Soils; ASTM International: West Conshohocken, PA, USA, 2016; Available online: https:/ /www.astm.org/Standards/D1883 (accessed on 14 October 2020).

72. Okeke CAU. Engineering behaviour of lime-and waste ceramic dust-stabilized expansive soil under continuous leaching. Bull. Eng. Geol. Environ. 2020, 79, 2169-2185. [CrossRef]

73. Obuzor, G.N.; Kinuthia, J.M.; Robinson, R.B. Utilisation of lime activated GGBS to reduce the deleterious effect of flooding on stabilised road structural materials: A laboratory simulation. Eng. Geol. 2011, 122, 334-338. [CrossRef]

74. Horpibulsuk, S.; Rachan, R.; Chinkulkijniwat, A.; Raksachon, Y.; Suddeepong, A. Analysis of strength development in cementstabilized silty clay from microstructural considerations. Constr. Build. Mater. 2010, 24, 2011-2021. [CrossRef]

75. Hossain, K.M.A.; Lachemi, M.; Easa, S. Stabilized soils for construction applications incorporating natural resources of Papua New Guinea. Resour. Conserv. Recycl. 2007, 51, 711-731. [CrossRef]

76. Kinuthia, J.M.; Wild, S.; Jones, G.I. Effects of monovalent and divalent metal sulphates on consistency and compaction of lime-stabilised kaolinite. Appl. Clay Sci. 1999, 14, 27-45. [CrossRef]

77. Anday, M.C. Curing Lime-Stabilized Soils. Natl. Res. Counc. Highw. Res. Rec. 1963, 29, 13-26. Available online: http:/ / onlinepubs.trb. org/Onlinepubs/hrr/1963/29/29-002.pdf (accessed on 15 October 2020).

78. Federal Ministry of Works and Housing. Federal Ministry of Works: Highway Manual (Part 1): Design. Pavement and Materials Design; Federal Ministry of Works and Housing: Abuja, Nigeria, 2013; Volume 3.

79. Al-Mukhtar, M.; Khattab, S.; Alcover, J.F. Microstructure and geotechnical properties of lime-treated expansive clayey soil. Eng. Geol. 2012, 139, 17-27. [CrossRef] 
80. Ahmed, A.; Issa, U.H. Stability of soft clay soil stabilised with recycled gypsum in a wet environment. Soils Found. 2014, 54, 405-416. [CrossRef]

81. Bhurtel, A.; Eisazadeh, A. Strength and Durability of Bottom Ash and Lime Stabilized Bangkok Clay. Ksce, J. Civ. Eng. 2020, $24,404-411$. [CrossRef]

82. Maaitah, O.N. Soil stabilization by chemical agent. Geotech. Geol. Eng. 2012, 30, 1345-1356. [CrossRef]

83. Saride, S.; Puppala, A.J.; Chikyala, S.R. Swell-shrink and strength behaviors of lime and cement stabilized expansive organic clays. Appl. Clay Sci. 2013, 85, 39-45. [CrossRef]

84. Al-Mukhtar, M.; Lasledj, A.; Alcover, J.F. Behaviour and mineralogy changes in lime-treated expansive soil at $20^{\circ} \mathrm{C}$. Appl. Clay Sci. 2010, 50, 191-198. [CrossRef]

85. Khadka, S.D.; Jayawickrama, P.W.; Senadheera, S.; Segvic, B. Stabilization of highly expansive soils containing sulfate using metakaolin and fly ash based geopolymer modified with lime and gypsum. Transp. Geotech. 2020, 23, 100327. [CrossRef]

86. Sergeyev, Y.M.; Grabowska-Olszewska, B.; Osipov, V.I.; Sokolov, V.N.; Kolomenski, Y.N. The classification of microstructures of clay soils. J. Microsc. 1980, 120, 237-260. [CrossRef]

87. Bhuvaneshwari, S.; Robinson, R.G.; Gandhi, S.R. Behaviour of lime treated cured expansive soil composites. Indian Geotech. J. 2014, 44, 278-293. [CrossRef]

88. Ng, C.W.; Akinniyi, D.B.; Zhou, C.; Chiu, C.F. Comparisons of weathered lateritic, granitic and volcanic soils: Compressibility and shear strength. Eng. Geol. 2019, 249, 235-240. [CrossRef]

89. Indraratna, B.; Nutalaya, P. Some engineering characteristics of a compacted lateritic residual soil. Geotech. Geol. Eng. 1991, 9, 125-137. [CrossRef]

90. Kamtchueng, B.T.; Onana, V.L.; Fantong, W.Y.; Ueda, A.; Ntouala, R.F.; Wongolo, M.H.; Ndongo, G.B.; Ze, A.N.; Kamgang, V.K.; Ondoa, J.M. Geotechnical, chemical and mineralogical evaluation of lateritic soils in humid tropical area (Mfou, CentralCameroon): Implications for road construction. Int. J. Geo-Eng. 2015, 6, 1. [CrossRef] 